Check for updates

Cite this: DOI: $10.1039 /$

d0md00208a

Received 16th June 2020

Accepted 27th July 2020

DOI: 10.1039/d0md00208a

rsc.li/medchem

\section{Synthesis and biological screening of a library of macamides as TNF- $\alpha$ inhibitors $\uparrow$}

\author{
Víctor Tena Pérez, ${ }^{a}$ Luis Apaza Ticona, (D)*ab Andreea Madalina Serban, ${ }^{c}$ \\ Javier Acero Gómez $z^{a}$ and Ángel Rumbero Sánchez ${ }^{a}$
}

\section{Introduction}

Our immune system is an incredible network of cells that protects us from all kinds of diseases. However, sometimes the system can be faulty and misinterpret the signals, causing our immune system to not recognise its own body and start attacking itself. ${ }^{1}$ The functioning of the immune system is regulated by the activity of pro and anti-inflammatory mediators. The imbalance of any of these mediators can lead to the development of increased susceptibility to infections, autoimmune diseases, and chronic inflammatory conditions. ${ }^{2}$ Currently, therapeutic investigations have focused on suppressing the production of pro-inflammatory mediators and on inhibiting the activation of the immune response, using modulation of TNF- $\alpha$, NF-kB, STAT3 and IFN- $\gamma$ signalling pathways. ${ }^{3}$

In particular, the use of inhibitors against the production and biological activity of the tumour necrosis factor alpha $\left(\right.$ TNF- $\alpha$ ) has been widely described and discussed. ${ }^{4}$ This is because this factor plays an important role in inflammatory

\footnotetext{
${ }^{a}$ Department of Organic Chemistry, Faculty of Sciences, University Autónoma of Madrid, Cantoblanco, 28049 Madrid, Spain.E-mail: luis.apaza@uam.es, Inapaza@ucm.es

${ }^{b}$ Department of Pharmacology, Pharmacognosy and Botany, Faculty of Pharmacy, University Complutense of Madrid, Ciudad Universitaria s/n, 28040 Madrid, Spain ${ }^{c}$ Maria Sklodowska Curie University Hospital for Children, Constantin Brancoveanu Boulevard, 077120 Bucharest, Romania

$\dagger$ Electronic supplementary information (ESI) available: ${ }^{1} \mathrm{H}-$ and ${ }^{13} \mathrm{C}-\mathrm{NMR}$ spectra of the synthetic macamides analysed in this study are provided as supporting information (Fig. 1S-70S). See DOI: 10.1039/d0md00208a
}

disorders related to diseases with various etymologies. These diseases can come from an infectious origin (meningitis, tuberculosis, acquired immunodeficiency syndrome), a tumour (prostate cancer, lung cancer, breast cancer) or have an autoimmune origin (inflammatory bowel disease, rheumatoid arthritis, lupus). ${ }^{5}$ Several drugs (e.g. dexamethasone) commonly used as immune-suppressants have been used to modulate the TNF- $\alpha$ activity, although their effects are associated with considerable toxicity. ${ }^{6}$

In the search for new compounds that involve the inhibition of TNF- $\alpha$ and its activity in cells, while presenting less toxicity, with greater potency and, thus, offering better clinical alternatives, our research suggests a series of chemical modifications to natural macamides which have been reported as having anti-inflammatory potential (TNF- $\alpha$ inhibitors). ${ }^{7}$

Macamides are secondary metabolites of the species Lepidium meyenii "Maca" and Tropaeolum tuberosum "Mashua" that grow exposed to extreme climatic conditions (poor soils with a slightly acidic pH between 5-6 and exposure to ultraviolet radiation at altitudes of 3.800 meters above sea level), producing this type of compounds considered as biomarkers of these species. Chemically, macamides consist of a residue of a benzylamine (product of the hydrolysis of glucosinolates by the enzyme myrosinase) and a fatty acid residue (product of the hydrolysis of membrane lipids). ${ }^{10}$

Recent pharmacological studies have shown that macamides have also other activities such as antioxidants, analgesics and antidepressants; ${ }^{11}$ anti-tuberculosis; ${ }^{12}$ anticholesterolemics; ${ }^{13}$ antifibrogenics; ${ }^{14}$ anticonvulsants; ${ }^{15}$ neuroprotectives ${ }^{16}$ and anticancer, ${ }^{17}$ being interesting 
molecules for chemical studies due to their wide pharmacological spectrum use.

The objective of the present work is to conclude on how the anti-inflammatory potential of macamides can be improved through the use of synthesised analogues. For this study, we first determined the cytotoxicity of the synthetic macamides, as their effect may hide anti-inflammatory activity. Subsequently, we evaluated their inhibitory activity on TNF- $\alpha$ in the THP-1 cell line.

\section{Results and discussion}

In order to improve the pharmacological profile of macamides as potential anti-inflammatory agents (TNF- $\alpha$ inhibition), we proceeded to carry out a chemical synthesis of structural analogues, by means of various modifications in the positions considered of greatest importance (Fig. 1).

The synthetic pathway was performed using an amidation reaction (modification of the Steglich reaction ${ }^{18,19}$ ) between the corresponding carboxylic acid and the benzylamine with $N, N^{\prime}$-dicyclohexylcarbodiimide (DCC), as shown in Scheme 1.

Concerning the alkyl chain, it was observed that its elongation (derivatives $\mathbf{1 a} \rightarrow \mathbf{1 d}$ ) does not generate a change in cytotoxicity (MTT) in the THP-1 cell line. However, synthetic macamide 1a (four-carbon alkyl chain) did not show a relevant inhibition on TNF- $\alpha$, it exhibited the same value as the free carboxylic acid (oleic acid). This effect is due to the increase in the number of carbon atoms present in the chain, leading to an increase in the biological activity. ${ }^{20}$ In this sense, derivative 1d showed TNF- $\alpha$ inhibition with an $\mathrm{IC}_{50}$ of $16.6 \pm 1.59 \mu \mathrm{M}$. Analysing the $n$-octanol/water partition coefficients $(\operatorname{cog} P$ ) of derivatives $\mathbf{1 a} \rightarrow \mathbf{1 d}$, a relationship between lipophilicity and biological activity was observed, and this is justified by the fact that increases in lipophilicity lead to an improvement in biological activity (Table 1). Free oleic acid was tested as negative control to determine if it was responsible for the inhibitory activity. Yet, we saw that free carboxylic acid did not produce significant activity on the target due to its low liposolubility ( $\operatorname{cog} P=3.47)$ compared to derivative $1 \mathrm{~d}(\operatorname{clog} P=7.68)$.

This result can be justified by the lipophilicity effect, a physicochemical parameter that determines the ability of a substance to cross the biological membrane. ${ }^{21,22}$ Therefore, molecules with a longer chain length can more easily cross the cell barrier by diffusion.

After confirming that the aliphatic chain of C18 is the most suitable, the next step was to study the influence of the

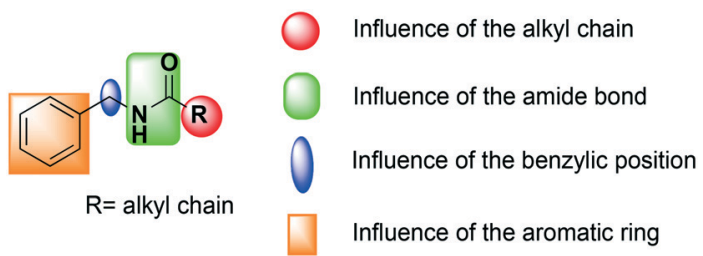

Fig. 1 General structure of macamide and positions explored on this study.

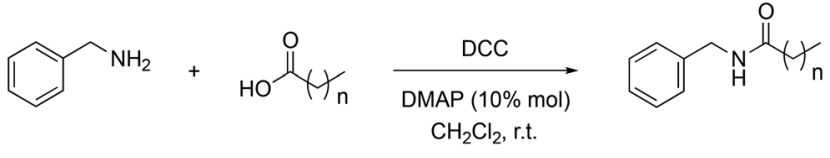

Scheme 1 Synthesis of macamide derivatives by means of the amidation reaction.

double bond. The oleic and linoleic fatty acids were used as precursors in order to obtain natural macamides ${ }^{23}$ through an amidation reaction.

The results reveal that the presence of double bonds improves TNF- $\alpha$ inhibition, due to the increased lipophilic capacity of derivatives $\mathbf{1 e}$ and $\mathbf{1 f}$ with respect to derivative 1d. $^{24}$ The difference between derivatives $1 \mathbf{e}$ and $\mathbf{1 f}$ was not statistically significant ( $\left.{ }^{\mathrm{ns}} p>0.999\right)$ (Table 1 ). Consequently, it was decided to use derivative 1 f for subsequent modifications, since this macamide is found in a greater proportion in nature ${ }^{25}$ and because it showed considerable biological activity $(14.2 \pm 1.47 \mu \mathrm{M})$.

After the promising results, it was decided to continue the pharmacomodulation study with the synthesis of homologues (through the addition or subtraction of methylene groups) on the benzylic position. We started from $(9 Z, 12 Z)$-octadeca-9,12dienoyl chloride and used different amines, from aniline $(n=$ $0)$ to 3-phenyl-1-propylamine $(n=3)$, obtaining the corresponding synthetic macamides $(\mathbf{1} \mathbf{g} \rightarrow \mathbf{1 i})$ (Scheme 2).

Analysing the results, it was observed that as the number of methylenes increased, their lipophilic capacity increased and, in turn, their biological activity was higher. In the case of derivative $\mathbf{1 h}$, the variation with respect to derivative 1f was not statistically significant $\left({ }^{\mathrm{ns}} p>0.999\right)$, but, after the introduction of a second methylene group (1i), the effect was more pronounced $\left(\mathrm{IC}_{50}=8.3 \pm 0.49\right.$ $\mu \mathrm{M})$. However, derivative $\mathbf{1 i}$ showed a cytotoxic effect $\left(\mathrm{CC}_{50}=80.3 \pm 1.31 \mu \mathrm{M}\right)$ on THP-1 cells and the difference was statistically significant with respect to derivative $\mathbf{1 f}$ $(* * * p<0.001)$ (Table 1).

These data can be justified based on electronic distribution, in which nitrogen, being a strong activator, modifies the electronic distribution of the aromatic ring and, consequently, its interaction $^{26}$ as observed when comparing derivatives $\mathbf{1 f}$ and $\mathbf{1 i}$.

The next phase of the investigation of the structureactivity relationship was to study the influence of substituents on the benzylic position. Due to the decrease in yield when the alkyl chain length is increased using an amidation reaction, (9Z,12Z)-octadeca-9,12-dienoyl chloride was used as a synthesis precursor instead of oleic acid, following Scheme 3.

To understand how this position affects activity, the following substitutions in the benzyl position have been tested: hydrazide residue (2a), methyl residue (2b), ethyl residue (2c), hydroxyethyl residue (2d) and gem-dimethyl residue (2e). The data revealed that the substitution at the benzylic position affected biological activity. Synthetic 
Table 1 Influence of the length of the alkyl chain, degree of unsaturation in the alkyl chain and structural homology of the synthetic macamides on TNF- $\alpha$

\begin{tabular}{|c|c|c|c|c|}
\hline No. & Derivatives & Viability $\left(\mathrm{CC}_{50} \mu \mathrm{M}\right)$ THP-1 cells & TNF- $\alpha$ inhibition $\left(\mathrm{IC}_{50} \mu \mathrm{M}\right)$ THP-1 cells & $\operatorname{clog} P^{a}$ \\
\hline Oleic acid & 0 & $100 \pm 1.99$ & $79.0 \pm 1.78$ & 3.47 \\
\hline $1 \mathbf{a}$ & & $100 \pm 1.71$ & $78.4 \pm 1.19$ & 1.70 \\
\hline $1 \mathbf{b}$ & & $100 \pm 1.66$ & $58.7 \pm 1.61$ & 4.01 \\
\hline 1c & & $100 \pm 1.98$ & $43.1 \pm 1.77$ & 6.30 \\
\hline 1d & & $100 \pm 1.83$ & $16.6 \pm 1.59$ & 7.68 \\
\hline $1 e$ & & $97.3 \pm 1.18$ & $15.2 \pm 1.51$ & 8.31 \\
\hline 1f & & $98.4 \pm 1.43$ & $14.2 \pm 1.47$ & 7.96 \\
\hline $1 \mathrm{~g}$ & & $97.8 \pm 1.22$ & $21.0 \pm 1.45$ & 7.82 \\
\hline $1 \mathrm{~h}$ & & $88.15 \pm 1.20$ & $15.7 \pm 1.69$ & 8.28 \\
\hline $1 \mathbf{i}$ & & $80.3 \pm 1.31$ & $8.3 \pm 0.49$ & 8.60 \\
\hline
\end{tabular}

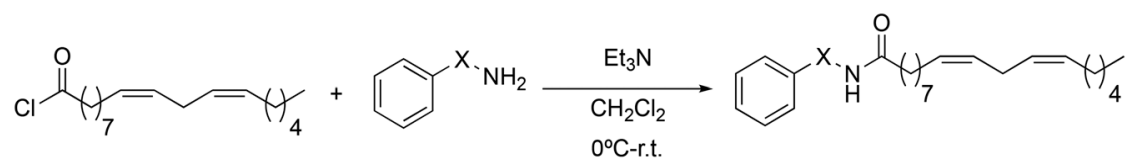

Scheme 2 Synthesis of $1 \mathrm{~g} \rightarrow 1 \mathrm{i}$ macamide derivatives.

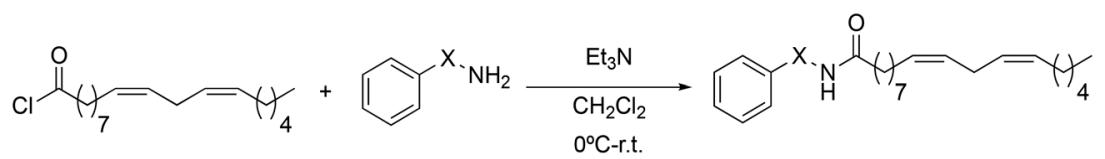

Scheme 3 Synthesis of $2 a \rightarrow 2 e$ macamide derivatives.

macamide 2a, which presents a hydrazide bond instead of amide, improved biological activity, exhibiting an $\mathrm{IC}_{50}$ of 8.9 $\pm 0.98 \mu \mathrm{M}$. Also, substitution in the benzylic position by a methyl group (2b), significantly improved the activity $\left(\mathrm{IC}_{50}\right.$ of $5.2 \pm 0.81 \mu \mathrm{M})$. This result is due to the greater lipophilic capacity of derivative $2 \mathbf{b}(\operatorname{cog} P=8.20)$ compared to derivative 2a $(\operatorname{cog} P=7.40)$ (Table 2$)$.
In the case of derivatives $2 \mathbf{c}$ and $2 \mathbf{e}$, although they have a greater lipophilic capacity than derivative $\mathbf{2 b}$, they showed less biological activity. This effect can be justified by the fact that its substituents have a higher volume that prevents correct interaction with the target. Regarding the low biological activity of the derivative $\mathbf{2 d}$, this result is due to its lower lipophilic capacity with respect to derivative $\mathbf{2 a}$. 
Table 2 Influence of the substitution in the benzylic position and modified analogues at the amide bond of the synthetic macamides on TNF- $\alpha$

\begin{tabular}{|c|c|c|c|c|}
\hline No. & Derivatives & Viability $\left(\mathrm{CC}_{50} \mu \mathrm{M}\right) \mathrm{THP}-1$ cells & TNF- $\alpha$ inhibition $\left(\mathrm{IC}_{50} \mu \mathrm{M}\right)$ THP- 1 cells & $\operatorname{clog} P^{a}$ \\
\hline $2 \mathbf{a}$ & & $98.1 \pm 1.84$ & $8.9 \pm 0.98$ & 7.40 \\
\hline $2 \mathbf{b}$ & & $95.8 \pm 1.97$ & $5.2 \pm 0.81$ & 8.20 \\
\hline $2 c$ & & $96.5 \pm 1.79$ & $19.7 \pm 1.94$ & 8.29 \\
\hline 2d & & $98.0 \pm 1.46$ & $56.8 \pm 1.75$ & 7.29 \\
\hline $2 \mathrm{e}$ & & $97.3 \pm 1.94$ & $13.1 \pm 1.74$ & 8.33 \\
\hline $2 f$ & & $89.1 \pm 1.23$ & $23.8 \pm 1.44$ & 8.11 \\
\hline $2 \mathrm{~g}$ & & $95.4 \pm 1.88$ & $6.4 \pm 0.91$ & 8.10 \\
\hline $2 \mathbf{h}$ & & $84.3 \pm 1.12$ & $5.3 \pm 0.75$ & 8.17 \\
\hline $2 \mathbf{i}$ & & $98.7 \pm 1.97$ & $1.6 \pm 0.07$ & 8.30 \\
\hline $2 \mathbf{j}$ & & $95.0 \pm 1.82$ & $0.97 \pm 0.02$ & 8.31 \\
\hline
\end{tabular}

Once the structure-activity study on the benzylic position was completed, we proceeded to analyse how the amide bond influences biological activity. At this point, changes were made to the amide bond. For this, the nitrogen-methylated derivative (2f), the benzyl ester (2g) and the benzyl thioester (2h) were synthesised (Scheme 4 ).

The synthetic macamide $2 \mathbf{i}$ was obtained reducing derivative $\mathbf{2 b}$ with $\mathrm{LiAlH}_{4}$ in a $90 \%$ yield (Scheme 5).

The synthetic macamide $2 \mathbf{j}$ was quantitatively synthesised from the reaction of the derivative $\mathbf{2} \mathbf{b}$ and Lawesson's reagent (Scheme 6).
The data revealed that the methylated nitrogen derivative 2f showed a lower biological activity $\left(\mathrm{IC}_{50}\right.$ of $\left.23.8 \pm 1.44 \mu \mathrm{M}\right)$ compared to derivative $\mathbf{1 f}\left(\mathrm{IC}_{50}\right.$ of $\left.14.2 \pm 1.47 \mu \mathrm{M}\right)$. This effect is due to the absence of hydrogen in the amide bond that allows the macamide to form a hydrogen bond with the target. Similarly, it was observed that derivative $2 \mathbf{f}$ did not show cytotoxicity $(\geq 90 \%)$.

Through the substitution of $\mathrm{N}-\mathrm{H}$ in the amide bond by other heteroatoms such as oxygen and sulphur, derivatives $\mathbf{2 g}$ and $\mathbf{2 h}$ had a favourable effect on the inhibition of TNF- $\alpha$, exhibiting $\mathrm{IC}_{50}$ values of $6.4 \pm 0.91$ and $5.3 \pm 0.75 \mu \mathrm{M}$ similar<smiles>[Y4]N=[W]</smiles>

Scheme 4 Synthesis of $2 \mathrm{f} \rightarrow 2 \mathrm{~h}$ macamide derivatives. 


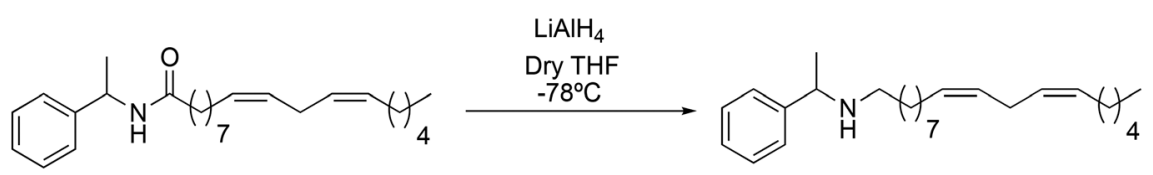

Scheme 5 Synthesis of 2i macamide derivative.

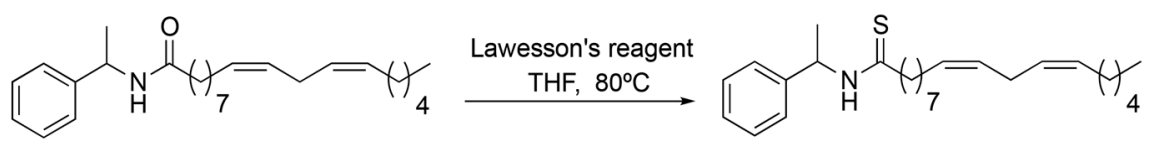

Scheme 6 Synthesis of 2j macamide derivative.

to those of derivative $2 \mathbf{b}\left(\mathrm{IC}_{50}=5.2 \pm 0.81 \mu \mathrm{M}\right)$, yet the difference was not statistically significant between them $\left({ }^{\mathrm{ns}} p\right.$ $>$ 0.999). Likewise, the similarity between these derivatives with respect to their activity is due to their lipophilic capacity in the range of 8.10-8.20 (Table 2).

To observe the influence of the amide bond on the biological activity, the carbonyl group of derivative $2 \mathbf{b}$ was modified obtaining the synthetic macamides (2j) and (2i). In both cases, there was an increase in TNF- $\alpha$ inhibition, with the value of derivative $2 \mathbf{j}$ standing out $\left(\mathrm{IC}_{50}=0.97 \pm 0.02 \mu \mathrm{M}\right)$. These results denote that alteration in the amide bond is key to biological activity. Likewise, it was observed that the increase in the biological activity of derivatives $2 \mathbf{j}$ and $2 \mathbf{i}$ was due to their greater lipophilic capacity with respect to derivative $\mathbf{2 b}$ (Table 2 ).

To end the first step of our study on the structure-activity relationship, we investigated the influence of the aromatic ring on the inhibition of TNF- $\alpha$. Changes were made to the position of the aromatic ring. For this, it was investigated if its presence was influential and how and if the introduction of substituents was relevant. In this sense, two types of derivatives were prepared: those in which the aromatic ring was replaced by alkyl groups (3a $\rightarrow \mathbf{3 c}$ ), and those in which the aromatic ring had different types of substituents $(\mathbf{3} \mathbf{d} \rightarrow \mathbf{3} \mathbf{j})$. In all cases, the synthetic methodology followed Scheme 7.

As it can be seen in Table 3, the changes made to the aromatic ring have a very favourable effect on the activity. When the benzene ring is replaced by a cyclohexyl group (3a), a tert-butyl group (3b), or an adamantyl group (3c), an improvement in biological activity occurs, showing $\mathrm{IC}_{50}$ values of $0.71 \pm 0.03,1.00 \pm 0.03$ and $0.78 \pm 0.02 \mu \mathrm{M}$, respectively, with respect to derivative $2 \mathbf{b}(5.2 \pm 0.81 \mu \mathrm{M})$. Likewise, derivatives $\mathbf{3 a}$ and $\mathbf{3} \mathbf{c}$ showed a greater lipophilic capacity with respect to derivative $\mathbf{2 b}$, determining their greater biological activity. These data demonstrate that aromaticity is not a key effect for activity.
Subsequently, it was decided to introduce electron donating groups (EDG) and electron withdrawing groups (EWG) in the aromatic ring to observe its effect on the biological activity. Although all substitutions improved activity with respect to derivative $\mathbf{2} \mathbf{b}$, the trend shows that substitutions with strong EDG and $\mathrm{EWG}^{28}$ (3d and $3 \mathbf{j}$ ) generate worse results with respect to derivatives that have weak EDG and $\mathrm{EWG}^{29,30}$ (3f, $3 \mathbf{h}$ and $3 \mathbf{i}$ ). This effect is due to the greater lipophilic capacity of these derivatives $(\mathbf{3} \mathbf{f}=8.14 ; \mathbf{3 h}=8.04$ and $\mathbf{3} \mathbf{i}=8.37)$ (Table 3$)$.

Regarding the cytotoxicity of this series of derivatives, the synthetic macamides $\mathbf{3 g}$, $3 \mathbf{h}$ and $3 \mathbf{i}$ showed a $\mathrm{CC}_{50}$ of $82.3 \pm$ $1.73 ; 82.5 \pm 1.86$ and $81.4 \pm 1.80 \mu \mathrm{M}$, being cytotoxic $(\geq 90 \%)$ on THP-1 cells. In the case of derivative $3 \mathbf{j}$, its $\mathrm{CC}_{50}$ of $89.8 \pm$ $1.30 \mu \mathrm{M}$ was not statistically significant $\left({ }^{\mathrm{ns}} p>0.999\right)$ with respect to the negative control (untreated cells).

Moreover, analysing previous works, we observed that the natural macamide $N$-oleoyldopamine $\left(\mathrm{IC}_{50}=3.54 \pm 0.02 \mu \mathrm{M}\right)$ showed a lower activity with respect to the natural macamide $N$-(2-hydroxyethyl)-7Z,10Z,13Z,16Z-docosatetraenamide $\left(\mathrm{IC}_{50}=\right.$ $1.77 \pm 0.07 \mu \mathrm{M}) .{ }^{9}$ This effect is due to the fact that the second macamide showed a greater length of the alkyl chain with a greater number of double bonds. In our work, synthetic macamide 3d is an improved derivative of natural macamide $\mathrm{N}$-oleoyldopamine. From a chemical point of view, the increase in the activity of the $\mathbf{3 d}$ derivative with respect to $\mathrm{N}$-oleoyldopamine is due to the presence of an additional double bond, decrease of methylene groups in the benzyl position and addition of a methyl residue in the benzyl position.

The substituent that exhibited the best biological activity was derivative 3f, which has a weak EDG (methyl residue) at the para position of the aromatic ring, with an $\mathrm{IC}_{50}$ of $0.62 \pm$ $0.03 \mu \mathrm{M}$. Based on this result, it was verified how the introduction of an ethyl group in the para position (3j) affects the activity, and it was observed that the introduction of one more carbon atom generates a decrease in biological activity $\left(\mathrm{IC}_{50}\right.$ of $\left.1.21 \pm 0.04 \mu \mathrm{M}\right)$.

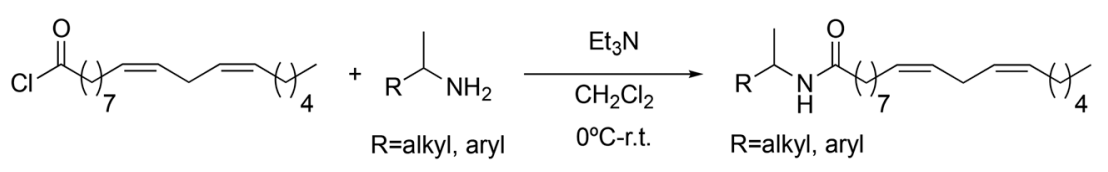

Scheme 7 Synthesis of $3 \mathbf{a} \rightarrow 3 \mathbf{j}$ macamide derivatives. 
Table 3 Influence of the aromatic ring and the position of methyl on the aromatic ring of the synthetic macamides on TNF- $\alpha$

\begin{tabular}{|c|c|c|c|c|}
\hline No. & Derivatives & Viability $\left(\mathrm{CC}_{50} \mu \mathrm{M}\right)$ THP-1 cells & TNF- $\alpha$ inhibition $\left(\mathrm{IC}_{50} \mu \mathrm{M}\right)$ THP- 1 cells & $\operatorname{cog} P^{a}$ \\
\hline $3 \mathbf{b}$ & & $94.7 \pm 1.25$ & $1.00 \pm 0.03$ & 8.07 \\
\hline 3d & & $93.5 \pm 1.58$ & $1.84 \pm 0.03$ & 8.00 \\
\hline $3 f$ & & $95.0 \pm 1.98$ & $0.62 \pm 0.03$ & 8.31 \\
\hline $3 \mathrm{~g}$ & & $82.3 \pm 1.73$ & $1.52 \pm 0.04$ & 7.99 \\
\hline $3 \mathbf{h}$ & & $82.5 \pm 1.86$ & $0.78 \pm 0.03$ & 8.04 \\
\hline $3 \mathbf{k}$ & & $92.5 \pm 1.64$ & $0.54 \pm 0.03$ & 8.20 \\
\hline 31 & & $91.7 \pm 1.19$ & $0.33 \pm 0.02$ & 8.31 \\
\hline $3 \mathrm{~m}$ & & $93.2 \pm 1.53$ & $0.08 \pm 0.001$ & 8.50 \\
\hline
\end{tabular}

In view of the data, it was decided to analyse how the position of methyl on the aromatic ring influences biological activity. The variation of the position within the ring causes a considerable improvement in the biological activity; this effect is especially relevant when the substitution is made in the meta position (31), where the corresponding amide had an $\mathrm{IC}_{50}$ of $0.33 \pm 0.02 \mu \mathrm{M}$. Based on this value, it was decided to study the di-substitution at the meta position, obtaining the best derivative substituted in the aromatic ring (3m), presenting an $\mathrm{IC}_{50}$ of $0.08 \pm 0.001 \mu \mathrm{M}$. These data demonstrate the strong dependence between the geometry of the synthetic macamide and the biological activity, resulting in the modification on the aromatic ring, showing that this is the position of the most influential pharmacophore (Table 3). 
Accounting for these results, it was decided to analyse how the position of the methyl in the aromatic ring influences biological activity. The variation of the position within the ring caused a considerable improvement in the biological activity. This effect was especially relevant when the substitution was made in the meta position, where the derivative 31 presented an $\mathrm{IC}_{50}$ of $0.33 \pm 0.02 \mu \mathrm{M}$. Based on this observation, we decided to study the di-substitution in the meta position, obtaining the derivative $3 \mathbf{m}$, with an $\mathrm{IC}_{50}$ of $0.08 \pm 0.001 \mu \mathrm{M}$. Likewise, derivative $3 \mathrm{~m}$ showed a greater lipophilic capacity with respect to derivative $\mathbf{2 b}$. These data demonstrate the strong dependence between the geometry of the synthetic macamide and the biological activity, confirming once more that this is the position of the most influential pharmacophore (Table 3).

Finally, compiling the information on the influence of the alkyl chain (aliphatic chain lengthening, 1f), the position of the benzyl (introduction of a methyl residue, $2 \mathbf{b}$ ), the modification of the amide bond (ester, 2g; amine, $2 \mathbf{i}$ and thioamide, $2 \mathbf{j}$ ) and the introduction of substituents on the aromatic ring (two methyl groups at the meta position, $3 \mathbf{m}$ ), it was decided to synthesise analogues with the optimal substituents at each position to analyse their biological activity. The synthetic methodology used to obtain the synthetic macamide $\mathbf{4 a}$ was the same as that used to synthesise derivative $\mathbf{2 g}$, reacting the acid chloride with an alcohol. In the case of the synthetic macamide $\mathbf{4 b}$, it was obtained starting from the reduction of the derivative $\mathbf{3 m}$ with $\mathrm{LiAlH}_{4}$. Finally, to obtain synthetic macamide 4c, derivative $3 \mathbf{m}$ was reacted with Lawesson's reagent.

The introduction of the thiocarbonyl group (4c) achieved a slight improvement in activity with an $\mathrm{IC}_{50}$ of $0.06 \pm 0.001 \mu \mathrm{M}$. In the case of synthetic macamide $\mathbf{4 b}$, as expected, in view of the previous results, the effect was more pronounced with an $\mathrm{IC}_{50}$ of $0.05 \pm 0.001 \mu \mathrm{M}$. Finally, synthetic macamide $4 \mathrm{a}$ showed the highest inhibitory effect with an $\mathrm{IC}_{50}$ of $0.009 \pm 0.001 \mu \mathrm{M}$. This effect could be justified on the basis of the difference between the amide bond and the ester bond, since the latter has less rigidity than the amide bond and could be adapted to the active centre of the target. Similarly, it was observed that, in this series of derivatives, synthetic macamide $4 \mathbf{c}$ showed a higher cytotoxicity $(71.5 \pm 1.13 \mu \mathrm{M})$ and synthetic macamide $3 \mathbf{b}$ showed a moderate cytotoxicity $(80.9 \pm 1.96 \mu \mathrm{M})$ with respect to untreated cells (negative control) (Table 4).

Our results show that the synthesised macamides and especially derivative $\mathbf{4 a}$ have a pharmacological potency between 200-400 times better than the natural $N$-(2hydroxyethyl)-7Z,10Z,13Z,16Z-docosatetraenamide and $N$-oleoyldopamine macamides that inhibit TNF- $\alpha$ in THP-1 cells with $\mathrm{IC}_{50}$ of $1.77 \pm 0.07$ and $3.54 \pm 0.02 \mu \mathrm{M}$, respectively, ${ }^{7}$ and 12 times better than the positive control (C87) with an $\mathrm{IC}_{50}$ of $0.11 \pm 0.01 \mu \mathrm{M}$ (Table 4 ).

Previous works showed that the anti-inflammatory activity of natural macamides is due to the inhibitory capacity of NF$\kappa \mathrm{B}$ activation induced by TNF- $\alpha$, through the direct inhibition of the IKK $\beta$ subunit and, to a smaller extent, of the IKK $\alpha$

Table 4 Comparative study of the optimal synthetic macamides against natural macamides and the positive control C87 on TNF- $\alpha$

\begin{tabular}{|c|c|c|c|c|}
\hline No. & Derivatives & Viability $\left(\mathrm{CC}_{50} \mu \mathrm{M}\right) \mathrm{THP}-1$ cells & TNF- $\alpha$ inhibition $\left(\mathrm{IC}_{50} \mu \mathrm{M}\right)$ THP-1 cells & $\operatorname{clog} P^{a}$ \\
\hline $4 a$ & & $90.1 \pm 1.27$ & $0.009 \pm 0.001$ & 9.09 \\
\hline $4 \mathbf{b}$ & & $80.9 \pm 1.96$ & $0.05 \pm 0.001$ & 9.19 \\
\hline $4 c$ & & $71.5 \pm 1.13$ & $0.06 \pm 0.001$ & 8.75 \\
\hline 1 & $\mathrm{HO}$ & $>100$ & $3.54 \pm 0.02$ & 8.79 \\
\hline 2 & & $>100$ & $1.77 \pm 0.07$ & 6.58 \\
\hline $\mathrm{C} 87$ & & $10.81 \pm 1.23$ & $0.11 \pm 0.01$ & 4.57 \\
\hline
\end{tabular}

${ }^{a}$ Values of $\operatorname{clog} P$ were calculated by DataWarrior. ${ }^{27} 1=N$-oleoyldopamine; $2=N$-(2-hydroxyethyl)-7Z,10Z,13Z,16Z-docosatetraenamide. 
subunit of the $\kappa \mathrm{B}$ kinase inhibitor complex. ${ }^{7,25}$ In this sense, we can indicate that the derivatives synthesised in this work lead to direct inhibition of $\mathrm{I} \kappa \mathrm{B}$, preventing its degradation and the subsequent inhibition of NF- $\kappa \mathrm{B}$ activation. ${ }^{7,31}$ These results open the way to the development of new antiinflammatory drugs with a better safety profile compared to the drugs available on the market.

\section{Material and methods}

\subsection{General experimental procedures}

NMR spectra were performed on a Bruker Avance AV-I operating at $300 \mathrm{MHz}\left({ }^{1} \mathrm{H}\right)$ or $75 \mathrm{MHz}\left({ }^{13} \mathrm{C}\right)$. The chemical shifts $(\delta)$ are indicated in ppm relative to the residual signals of deuterated solvent: $\delta_{\mathrm{H}} 7.26$ and $\delta_{\mathrm{C}} 77.2$ for $\mathrm{CDCl}_{3} \cdot{ }^{13} \mathrm{C} \mathrm{NMR}$ spectra were acquired in a proton decoupled broadband system. The following abbreviations were used to describe the peak patterns: s (singlet), d (doublet), t (triplet), q (quartet), quint (quintet), sext (sextuplet), sept (septuplet), m (multiplet) and br (broad signal). High resolution mass spectrometry (HRMS) was recorded on a quadrupole QSTAR XL spectrometer with TOF, electrospray (ESI+). In each case, the solvent and concentration used (mg $\left.\mathrm{mL}^{-1}\right)$ were indicated. TLC was performed using Merck silica gel $60-\mathrm{F}_{254}$ plates. Developed chromatograms were visualised by UV absorbance $(254 \mathrm{~nm})$ or through application of heat to a plate stained with phosphomolybdic acid $\left(\mathrm{H}_{3} \mathrm{PMo}_{12} \mathrm{O}_{40}\right)$. The manual chromatography column was performed with silica gel $(60 \mu \mathrm{m})$ and with the indicated eluent in accordance with standard techniques. The solvents and reagents used were purchased from commercial sources and used without prior purification.

\subsection{General procedure for the acylation of benzylamine with fatty acids}

The corresponding carboxylic acid (1 eq.) was added in a round bottom flask and dissolved in dry $\mathrm{CH}_{2} \mathrm{Cl}_{2}(1 \mathrm{~mL}$ $\mathrm{mmol}^{-1}$ carboxylic acid). Subsequently, the DCC (1.2 eq.) was added. The mixture was kept under stirring for 15 minutes, after which a mixture of DMAP $(10 \% \mathrm{~mol})$ and benzylamine (1 eq.) dissolved in dry $\mathrm{CH}_{2} \mathrm{Cl}_{2}\left(1 \mathrm{~mL} \mathrm{mmol}^{-1}\right.$ benzylamine) was added. The reaction mixture was kept stirred for $12 \mathrm{~h}$ at room temperature. At the end of this time, the white solid formed was filtered through a filter plate and the solvent was removed from the filtrate by evaporation under reduced pressure. The crude reaction was purified by flash chromatography using Hex-AcOEt as eluent.

\subsection{Synthesis of $(9 Z, 12 Z)-N^{\prime}$-phenyloctadeca-9,12- dienehydrazide}

In a solution of phenylhydrazine $(215 \mathrm{mg}, 2 \mathrm{mmol})$ in dry $\mathrm{CH}_{2} \mathrm{Cl}_{2}\left(3 \mathrm{~mL} \mathrm{mmol}{ }^{-1}\right), \mathrm{Et}_{3} \mathrm{~N}(201 \mathrm{mg}, 2 \mathrm{mmol})$ was added and stirred at $0{ }^{\circ} \mathrm{C}$. Next, $(9 Z, 12 Z)$-octadeca-9,12-dienoyl chloride (500 mg, $1.66 \mathrm{mmol}$ ) was added dropwise. After 10 minutes, the reaction was observed to be complete by TLC. Water was added and extraction was carried out with $\mathrm{CH}_{2} \mathrm{Cl}_{2}$
$2 \times 15 \mathrm{~mL}$. The organic phase was dried with anhydrous $\mathrm{MgSO}_{4}$, filtered and the solvent was removed under reduced pressure. (9Z,12Z)- $N$ '-phenyloctadeca-9,12-dienehydrazide (2a) was purified by flash chromatography with a mixture of HexAcOEt (2:1) as eluent; it was obtained as a colourless liquid with a yield of $70 \%$.

3.4. General procedure for the synthesis of $(9 Z, 12 Z)$-octadeca9,12-dienamide, $(9 Z, 12 Z)$-octadeca-9,12-dienoate derivatives and $(9 Z, 12 Z)$-octadeca-9,12-dienethioate derivatives

In a solution of the corresponding amine, alcohol or thiol (1.0 eq.) in dry $\mathrm{CH}_{2} \mathrm{Cl}_{2}$ (2 mL mmol$\left.{ }^{-1}\right), \mathrm{Et}_{3} \mathrm{~N}$ (1.2 eq.) was added and stirred at $0{ }^{\circ} \mathrm{C}$. Next, the $(9 Z, 12 Z)$-octadeca-9,12dienoyl chloride was added dropwise. After 10 minutes, the reaction was observed to have been completed by TLC. $\mathrm{HCl}$ $(10 \%)$ was added and the aqueous phase $2 \times 15 \mathrm{~mL}$ of $\mathrm{CH}_{2} \mathrm{Cl}_{2}$ was extracted. The organic phase was dried over anhydrous $\mathrm{MgSO}_{4}$, filtered, and the solvent was removed under reduced pressure. The crude reaction was purified by flash chromatography using Hex-AcOEt as eluent.

\subsection{General procedure for amide reduction}

$\mathrm{LiAlH}_{4}$ (5 eq.) was added to a flask with dry THF at $-78{ }^{\circ} \mathrm{C}$, and, subsequently, the corresponding amide (1 eq.) was added, drop by drop, dissolved in dry THF. Stirring was maintained for $12 \mathrm{~h}$. After the reaction was complete, hydrated $\mathrm{Na}_{2} \mathrm{SO}_{4}$ was added and allowed to react for 15 minutes until the formation of hydrogen was no longer observed. The solution was filtered and the solvent was removed under reduced pressure; the crude reaction was purified by flash chromatography using Hex-AcOEt as eluent.

\subsection{General procedure for obtaining thioamides}

In a solution of the corresponding amide (1.0 eq.) in dry THF, Lawesson's reagent (1.5 eq.) was added and it was stirred at reflux for $12 \mathrm{~h}$. After completion of the reaction, the solvent was removed under reduced pressure and the reaction crude was purified by flash chromatography using Hex-AcOEt as the eluent.

\subsection{Spectroscopic data}

$N$-Benzylbutyramide (1a). $N$-Benzylbutyramide (1a) was obtained from butanoic acid (300 mg, $3.41 \mathrm{mmol}$ ) and benzylamine (3.41 mmol). $508 \mathrm{mg}$ of the synthetic macamide 1a $(90 \%$ yield) were obtained as a white solid. The product was chromatographed with a Hex-AcOEt mixture $(3: 1) \cdot{ }^{1} \mathrm{H}$ NMR $\left(\mathrm{CDCl}_{3}, 300 \mathrm{MHz}\right): \delta_{\mathrm{H}} 0.94(\mathrm{t}, 3 \mathrm{H}, J=7.4 \mathrm{~Hz}), 1.66(\mathrm{~s}, 2 \mathrm{H}$, $J=7.4 \mathrm{~Hz}), 2.17(\mathrm{t}, 2 \mathrm{H}, J=7.5 \mathrm{~Hz}), 4.40(\mathrm{~d}, 2 \mathrm{H}, J=5.7 \mathrm{~Hz})$, 6.19 (bs, 1H), 7.29-7.16 (m, 5H). ${ }^{13} \mathrm{C} \mathrm{NMR}\left(\mathrm{CDCl}_{3}, 75 \mathrm{MHz}\right)$ : $\delta_{\mathrm{C}} 13.9,19.3,38.7,43.5,127.5,127.8,128.7,138.5,173.1$.

$\mathrm{N}$-Benzyloctanamide (1b). $\mathrm{N}$-Benzyloctanamide (1b) was obtained from octanoic acid (443 $\mathrm{mg}, 3.07 \mathrm{mmol}$ ) and benzylamine (329 mg, $3.07 \mathrm{mmol}) .620 \mathrm{mg}$ of the synthetic macamide $\mathbf{1 b}$ ( $81 \%$ yield) were obtained as a white solid. The 
product was chromatographed with a Hex-AcOEt mixture (3: 1). ${ }^{1} \mathrm{H} \mathrm{NMR}\left(\mathrm{CDCl}_{3}, 300 \mathrm{MHz}\right): \delta_{\mathrm{H}} 0.85(\mathrm{t}, 3 \mathrm{H}, J=7.1 \mathrm{~Hz})$, 1.26-1.17 (m, 8H), 1.63 (q, 2H, $J=7.4 \mathrm{~Hz}) 2.18(\mathrm{t}, 2 \mathrm{H}, J=7.7$ $\mathrm{Hz}), 4.41$ (d, 2H, $J=5.7 \mathrm{~Hz}), 5.80$ (bs, $1 \mathrm{H}), 7.28-7.19(\mathrm{~m}, 5 \mathrm{H})$. ${ }^{13} \mathrm{C} \mathrm{NMR}\left(\mathrm{CDCl}_{3}, 75 \mathrm{MHz}\right): \delta_{\mathrm{C}} 14.2,22.7,25.9,29.1,29.4$, 31.8, 36.9, 43.7, 127.5, 127.9, 128.8, 138.5, 173.1 .

$\mathrm{N}$-Benzylhexadecanamide (1c). $\mathrm{N}$-Benzylhexadecanamide (1c) was obtained from hexadecanoic acid (788 mg, 1.12 $\mathrm{mmol}$ ) and benzylamine (119 $\mathrm{mg}, 1.12 \mathrm{mmol}) .580 \mathrm{mg}$ of the synthetic macamide 1c (60\% yield) were obtained as a white solid. The product was purified with a Hex-AcOEt mixture (5:1). ${ }^{1} \mathrm{H} \mathrm{NMR}\left(\mathrm{CDCl}_{3}, 300 \mathrm{MHz}\right): \delta_{\mathrm{H}} 0.85(\mathrm{t}, 3 \mathrm{H}, J=7.2 \mathrm{~Hz})$, 1.26-1.17 (m, 24H), $1.61(\mathrm{q}, 2 \mathrm{H}, J=7.7 \mathrm{~Hz}), 2.18(\mathrm{t}, 2 \mathrm{H}, J=$ $7.4 \mathrm{~Hz}$ ), 4.41 (d, 2H, $J=5.7 \mathrm{~Hz}), 5.72$ (bs, 1H), 7.32-7.20 (m, $5 \mathrm{H}) .{ }^{13} \mathrm{C} \mathrm{NMR}\left(\mathrm{CDCl}_{3}, 75 \mathrm{MHz}\right): \delta_{\mathrm{C}} 14.3,22.8,25.9,29.4,29.5$, $29.5,29.6,29.7,29.8,29.8,29.8,29.9,29.9,32.0,36.9,43.7$, 127.6, 127.9, 128.8, 138.5, 173.1 .

$\mathrm{N}$-Benzyloctadecanamide (1d). $\mathrm{N}$-Benzyloctadecanamide (1d) was obtained from octadecanoic acid (611 mg, 2.15 $\mathrm{mmol}$ ) and benzylamine ( $230 \mathrm{mg}, 2.15 \mathrm{mmol}) .506 \mathrm{mg}$ of the synthetic macamide 1d (63\% yield) were obtained as a white solid. The product was chromatographed with a Hex-AcOEt mixture $(5: 1) .{ }^{1} \mathrm{H}$ NMR $\left(\mathrm{CDCl}_{3}, 300 \mathrm{MHz}\right): \delta_{\mathrm{H}} 0.88(\mathrm{t}, 3 \mathrm{H}, J=$ $7.2 \mathrm{~Hz}$ ), 1.28-1.17 (m, 28H), 1.65 (q, 2H, $J=7.7 \mathrm{~Hz}), 2.21(\mathrm{t}$, $2 \mathrm{H}, J=7.2 \mathrm{~Hz}$ ), 4.45 (d, 2H, $J=5.7 \mathrm{~Hz}$ ), 5.70 (bs, 1H), 7.32$7.20(\mathrm{~m}, 5 \mathrm{H}) .{ }^{13} \mathrm{C} \mathrm{NMR}\left(\mathrm{CDCl}_{3}, 75 \mathrm{MHz}\right): \delta_{\mathrm{C}} 13.8,22.4,25.5$, 29.0, 29.1, 29.1, 29.2, 29.3, 29.4, 29.4, 29.4, 29.5, 29.5, 29.5, 29.6, 31.7, 36.6, 43.3, 127.2, 127.5, 128.4, 138.2, 172.7.

(9Z)- $\mathrm{N}$-Benzyloctadec-9-enamide (1e). (9Z)- $\mathrm{N}$-Benzyloctadec9-enamide (1e) was obtained from oleic acid (500 mg, 1.77 $\mathrm{mmol}$ ) and benzylamine (189 $\mathrm{mg}, 1.77 \mathrm{mmol}$ ). $209 \mathrm{mg}$ of the synthetic macamide 1e (56\% yield) were obtained as a white solid. The product was chromatographed with a Hex-AcOEt mixture $(5: 1) .{ }^{1} \mathrm{H}$ NMR $\left(\mathrm{CDCl}_{3}, 300 \mathrm{MHz}\right): \delta_{\mathrm{H}} 0.83(\mathrm{t}, 3 \mathrm{H}, J=$ $7.0 \mathrm{~Hz}), 1.32-1.23(\mathrm{~m}, 20 \mathrm{H}), 1.62(\mathrm{q}, 2 \mathrm{H}, J=6.9 \mathrm{~Hz}), 2.02-1.85$ $(\mathrm{m}, 4 \mathrm{H}), 2.18(\mathrm{t}, 2 \mathrm{H}, J=7.2 \mathrm{~Hz}), 4.40(\mathrm{~d}, 2 \mathrm{H}, J=5.7 \mathrm{~Hz}), 5.37-$ $5.26(\mathrm{~m}, 2 \mathrm{H}) 5.70$ (bs, 1H), 7.34-7.22 (m, 5H). ${ }^{13} \mathrm{C}$ NMR $\left(\mathrm{CDCl}_{3}, 75 \mathrm{MHz}\right): \delta_{\mathrm{C}} 14.3,22.8,25.9,27.3,27.4,29.3,29.4$, 29.4, 29.4, 29.5, 29.7, 29.8, 29.9, 32.0, 37.0, 43.7, 127.6, 128.0, 128.8, 129.9, 130.1, 138.6, 173.0.

(9Z,12Z)-N-Benzyloctadeca-9,12-dienamide (1f). $(9 Z, 12 Z)-N$ Benzyloctadeca-9,12-dienamide (1f) was obtained from (9Z,12Z)-octadeca-9,12-dienoic acid (400 mg, $1.42 \mathrm{mmol}$ ) and benzylamine (151.9 mg, $1.42 \mathrm{mmol}$ ). $265 \mathrm{mg}$ of the synthetic macamide 1f (50\% yield) were obtained as a colourless liquid. The product was chromatographed with a Hex-AcOEt mixture $(5: 1) .{ }^{1} \mathrm{H}$ NMR $\left(\mathrm{CDCl}_{3}, 300 \mathrm{MHz}\right): \delta_{\mathrm{H}} 0.89(\mathrm{t}, 3 \mathrm{H}, J=$ $7.0 \mathrm{~Hz}), 1.31-1.20(\mathrm{~m}, 14 \mathrm{H}), 1.67-1.62(\mathrm{~m}, 2 \mathrm{H}), 2.07-2.01(\mathrm{~m}$, $4 \mathrm{H}), 2.21(\mathrm{t}, 2 \mathrm{H}, J=7.7 \mathrm{~Hz}), 2.77(\mathrm{t}, 2 \mathrm{H}, J=5.8 \mathrm{~Hz}), 4.44(\mathrm{~d}$, $2 \mathrm{H}, J=5.7 \mathrm{~Hz}), 5.47-5.23(\mathrm{~m}, 4 \mathrm{H}) 5.70(\mathrm{bs}, 1 \mathrm{H}), 7.32(\mathrm{~m}, 5 \mathrm{H})$. ${ }^{13} \mathrm{C} \mathrm{NMR}\left(\mathrm{CDCl}_{3}, 75 \mathrm{MHz}\right): \delta_{\mathrm{C}} 14.2,22.7,25.8,25.9,27.3$, 27.4, 29.3, 29.4, 29.5, 29.5, 29.7, 31.7, 37.0, 43.7, 127.6, 128.0, $128.1,128.2,128.9,130.2,130.4,138.6,173.0$. HRESIMS [M + $\mathrm{H}]^{+} \mathrm{m} / z 370.3102$ (calculated for $\mathrm{C}_{25} \mathrm{H}_{40} \mathrm{NO} 370.3104$ ).

(9Z,12Z)- $N$-Phenyloctadeca-9,12-dienamide (1g). (9Z,12Z)$N$-Phenyloctadeca-9,12-dienamide (1g) was obtained from
(9Z,12Z)-octadeca-9,12-dienoyl chloride (736 $\mathrm{mg}, 2.47 \mathrm{mmol}$ ) and aniline (230 mg, $2.47 \mathrm{mmol}$ ). $640 \mathrm{mg}$ of the synthetic macamide $1 \mathrm{~g}$ (73\% yield) were obtained as a yellowish liquid. The product was chromatographed with a Hex-AcOEt mixture (3:1). ${ }^{1} \mathrm{H} \mathrm{NMR}\left(\mathrm{CDCl}_{3}, 300 \mathrm{MHz}\right): \delta_{\mathrm{H}} 0.89(\mathrm{t}, 3 \mathrm{H}, J=6.8 \mathrm{~Hz})$, 1.34-1.17 (m, 14H), 1.73-1.60 (m, 2H), $2.05(\mathrm{q}, 4 \mathrm{H}, J=6.4$ $\mathrm{Hz}), 2.35(\mathrm{t}, 2 \mathrm{H}, J=7.7 \mathrm{~Hz}), 2.77(\mathrm{t}, 2 \mathrm{H}, J=6.0 \mathrm{~Hz}), 5.35-5.21$ $(\mathrm{m}, 4 \mathrm{H}), 7.10(\mathrm{t}, 1 \mathrm{H}, J=7.2 \mathrm{~Hz}), 7.18(\mathrm{bs}, 1 \mathrm{H}), 7.31(\mathrm{t}, 2 \mathrm{H}, J=$ $8.2 \mathrm{~Hz}), 7.51$ (d, $2 \mathrm{H}, J=7.8 \mathrm{~Hz}) .{ }^{13} \mathrm{C} \mathrm{NMR}\left(\mathrm{CDCl}_{3}, 75 \mathrm{MHz}\right)$ : $\delta_{\mathrm{C}} 14.1,22.6,25.6,25.8,27.2,29.2$, 29.3, 29.3, 29.6, 31.5, 37.6, $120.3,124.1,127.9,128.0,128.8,130.0,130.2$, 138.3, 172.3.

$(\mathbf{9 Z , 1 2 Z )}-\mathrm{N}$-Phenethyloctadeca-9,12-dienamide

(1h). (9Z,12Z)- $N$-Phenethyloctadeca-9,12-dienamide (1h) was obtained from $(9 Z, 12 Z)$-octadeca-9,12-dienoyl chloride (736 $\mathrm{mg}, 2.47 \mathrm{mmol}$ ) and phenethylamine (300 mg, $2.47 \mathrm{mmol}$ ). $663 \mathrm{mg}$ of the synthetic macamide $\mathbf{1 h}$ (70\% yield) were obtained as a yellowish liquid. The product was chromatographed with a Hex-AcOEt mixture $(4: 1) .{ }^{1} \mathrm{H}$ NMR $\left(\mathrm{CDCl}_{3}, 300 \mathrm{MHz}\right): \delta_{\mathrm{H}} 0.89(\mathrm{t}, 3 \mathrm{H}, J=6.9 \mathrm{~Hz}), 1.35-1.27(\mathrm{~m}$, $14 \mathrm{H}), 1.58-1.53(\mathrm{~m}, 3 \mathrm{H}), 2.15-2.03(\mathrm{~m}, 5 \mathrm{H}), 2.85-2.73(\mathrm{~m}$, $3 \mathrm{H}), 3.52(\mathrm{q}, 2 \mathrm{H}, J=6.8 \mathrm{~Hz}), 5.46-5.32(\mathrm{~m}, 4 \mathrm{H}), 7.35-7.18(\mathrm{~m}$, $5 \mathrm{H}) .{ }^{13} \mathrm{C} \mathrm{NMR}\left(\mathrm{CDCl}_{3}, 75 \mathrm{MHz}\right): \delta_{\mathrm{C}} 14.0,22.5,25.6,25.7,27.1$, 29.1, 29.2, 29.3, 29.6, 31.5, 35.6, 36.6, 40.6, 126.4, 127.9, 128.5, 128.7, 130.0, 130.1, 139.0, 173.4.

(9Z,12Z)- $N$-(3-Phenylpropyl)-octadeca-9,12-dienamide (1i). (9Z,12Z)- $N$-(3-Phenylpropyl)-octadeca-9,12-dienamide (1i), 250 $\mathrm{mg}$ of the amine were introduced and $573 \mathrm{mg}$ of the synthetic macamide 1i were obtained (78\% yield). Column with Hex-AcOEt $(6: 1)$ pale yellow liquid. ${ }^{1} \mathrm{H} \mathrm{NMR}\left(\mathrm{CDCl}_{3}\right.$, $300 \mathrm{MHz}): \delta_{\mathrm{H}} 0.89(\mathrm{t}, 3 \mathrm{H}, J=7.0 \mathrm{~Hz}), 1.40-1.24(\mathrm{~m}, 14 \mathrm{H})$, 1.69-1.56 (m, 3H), 1.84 (quint, $2 \mathrm{H}, J=7.0 \mathrm{~Hz}$ ), 2.15-2.02 (m, $5 \mathrm{H}$ ), 2.65 (t, 2H, $J=7.8 \mathrm{~Hz}), 2.77(\mathrm{t}, 2 \mathrm{H}, J=5.9 \mathrm{~Hz}), 3.29$ (q, $2 \mathrm{H}, J=6.9 \mathrm{~Hz}), 5.42-5.28(\mathrm{~m}, 4 \mathrm{H}), 7.22-7.15(\mathrm{~m}, 3 \mathrm{H}), 7.30-$ $7.26(\mathrm{~m}, 2 \mathrm{H}) .{ }^{13} \mathrm{C} \mathrm{NMR}\left(\mathrm{CDCl}_{3}, 75 \mathrm{MHz}\right): \delta_{\mathrm{C}} 14.0,22.5,25.6$, 25.8, 27.2, 29.1, 29.3, 29.3, 29.6, 31.2, 31.5, 33.3, 36.7, 39.2, 125.9, 127.9, 128.0, 128.3, 128.4, 130.0, 130.2, 141.5, 173.4.

(9Z,12Z)- $N^{\prime}$-Phenyloctadeca-9,12-dienehydrazide (2a). (9Z,12Z)-N'-Phenyloctadeca-9,12-dienehydrazide (2a) was obtained from phenylhydrazine (215 mg, $2 \mathrm{mmol}$ ), $\mathrm{CH}_{2} \mathrm{Cl}_{2}$ (3 $\left.\mathrm{mL} \mathrm{mmol}{ }^{-1}\right), \mathrm{Et}_{3} \mathrm{~N}(201 \mathrm{mg}, 2 \mathrm{mmol})$ and $(9 Z, 12 Z)$-octadeca9,12-dienoyl chloride (500 mg, $1.66 \mathrm{mmol}$ ). $350 \mathrm{mg}$ of synthetic macamide $2 \mathbf{a}$ (70\% yield) were obtained as a colourless liquid with a yield. The product was chromatographed with a HexAcOEt mixture (2:1). ${ }^{1} \mathrm{H}$ NMR $\left(\mathrm{CDCl}_{3}, 300 \mathrm{MHz}\right): \delta_{\mathrm{H}} 0.81(\mathrm{t}, 3 \mathrm{H}$, $J=7.1 \mathrm{~Hz}$ ), 1.40-1.22 (m, 14H), 1.72-1.59 (m, 2H), 2.08-1.97 (m, 4H), 2.18 (t, 1H, J = $7.8 \mathrm{~Hz}), 2.69$ (q, 2H, $J=5.2 \mathrm{~Hz}), 5.41-$ $5.27(\mathrm{~m}, 4 \mathrm{H}), 6.94-6.75(\mathrm{~m}, 2 \mathrm{H}), 7.38-7.19(\mathrm{~m}, 3 \mathrm{H}) .{ }^{13} \mathrm{C} \mathrm{NMR}$ $\left(\mathrm{CDCl}_{3}, 75 \mathrm{MHz}\right): \delta_{\mathrm{C}} 14.1,22.6,25.5,25.6,27.2,29.2,29.3,29.3$, 29.6, 31.5, 34.2, 113.5, 120.9, 127.9, 128.1, 129.0, 130.0, 130.2, 130.2, 148.1, 173.8 .

(9Z,12Z)- $N$-(1-Phenylethyl)-octadeca-9,12-dienamide (2b). (9Z,12Z)-N-(1-Phenylethyl)-octadeca-9,12-dienamide (2b) was obtained from $(9 Z, 12 Z)$-octadeca-9,12-dienoyl chloride (593 $\mathrm{mg}, 1.99 \mathrm{mmol}$ ) and 1-methyl benzylamine (241 mg, 1.99 mmol). $470 \mathrm{mg}$ of the synthetic macamide $2 \mathbf{b}$ ( $73 \%$ yield) were obtained as a yellowish liquid. The product was 
chromatographed with a Hex-AcOEt mixture $(5: 1) .{ }^{1} \mathrm{H}$ NMR $\left(\mathrm{CDCl}_{3}, 300 \mathrm{MHz}\right): \delta_{\mathrm{H}} 0.89(\mathrm{t}, 3 \mathrm{H}, J=7.0 \mathrm{~Hz}), 1.36-1.25(\mathrm{~m}$, $14 \mathrm{H}), 1.49$ (d, 3H, $J=6.9 \mathrm{~Hz}), 1.65-1.56(\mathrm{~m}, 4 \mathrm{H}), 2.04-2.00$ $(\mathrm{m}, 4 \mathrm{H}), 2.16(\mathrm{t}, 2 \mathrm{H}, J=7.8 \mathrm{~Hz}) 2.77(\mathrm{t}, 2 \mathrm{H}, J=5.9 \mathrm{~Hz}), 5.15$ (quint, $1 \mathrm{H}, J=7.1 \mathrm{~Hz}$ ), 5.43-5.29 (m, 4H), 5.61 (bd, 1H), 7.36$7.24(\mathrm{~m}, 5 \mathrm{H}) .{ }^{13} \mathrm{C} \mathrm{NMR}\left(\mathrm{CDCl}_{3}, 75 \mathrm{MHz}\right): \delta_{\mathrm{C}} 14.1,21.8,22.6$, 25.7, 25.8, 27.2, 29.2, 29.3, 29.3, 29.4, 29.6, 31.5, 36.8, 48.5, 126.2, 127.2, 127.9, 128.1, 128.6, 130.1, 130.2, 143.5, 172.3.

(9Z,12Z)- $N$-(1-Phenylpropyl)-octadeca-9,12-dienamide (2c). (9Z,12Z)- $N$-(1-Phenylpropyl)-octadeca-9,12-dienamide (2c) was obtained from $(9 Z, 12 Z)$-octadeca-9,12-dienoyl chloride (658 $\mathrm{mg}, 2.21 \mathrm{mmol}$ ) and 1-ethyl benzylamine (300 $\mathrm{mg}, 2.21$ $\mathrm{mmol}$ ). $608 \mathrm{mg}$ of the synthetic macamide $2 \mathrm{c}$ (69\% yield) were obtained as a yellowish liquid. The product was chromatographed with a Hex-AcOEt mixture $(5: 1) .{ }^{1} \mathrm{H}$ NMR $\left(\mathrm{CDCl}_{3}, 300 \mathrm{MHz}\right): \delta_{\mathrm{H}} 0.87(\mathrm{t}, 6 \mathrm{H}, J=7.4 \mathrm{~Hz}), 1.34-1.23(\mathrm{~m}$, $14 \mathrm{H}), 1.62-1.57(\mathrm{~m}, 4 \mathrm{H}), 1.85-1.74(\mathrm{~m}, 2 \mathrm{H}), 2.06-1.98(\mathrm{~m}, 3 \mathrm{H})$, $2.15(\mathrm{t}, J=7.8 \mathrm{~Hz}), 2.75(\mathrm{t}, 1 \mathrm{H}, J=5.7 \mathrm{~Hz}), 4.87(\mathrm{q}, 1 \mathrm{H}, J=7.3$ $\mathrm{Hz}), 5.41-5.26(\mathrm{~m}, 3 \mathrm{H}), 5.65$ (d, $1 \mathrm{H}, J=6.7 \mathrm{~Hz}), 7.34-7.22(\mathrm{~m}$, $5 \mathrm{H}) .{ }^{13} \mathrm{C} \mathrm{NMR}\left(\mathrm{CDCl}_{3}, 75 \mathrm{MHz}\right): \delta_{\mathrm{C}} 10.8,14.1,22.6,25.7,25.9$, 27.3, 29.2, 29.2, 29.3, 29.3, 29.4, 29.7, 31.6, 36.9, 54.8, 126.7, 127.3, 128.0, 128.1, 128.6, 130.1, 130.3, 142.4, 172.6 .

(9Z,12Z)- $\mathrm{N}$-(2-Hydroxy-1-phenylethyl)-octadeca-9,12-

dienamide (2d). (9Z,12Z)- $N$-(2-Hydroxy-1-phenylethyl)-octadeca9,12-dienamide (2d) was obtained from $(9 Z, 12 Z)$-octadeca-9,12dienoyl chloride (593 mg, $2.18 \mathrm{mmol}$ ) and DL-2-phenylglycinol (300 mg, $2.18 \mathrm{mmol}$ ). $535 \mathrm{mg}$ of the synthetic macamide $2 \mathrm{~d}$ (77\% yield) were obtained as a yellowish liquid. The product was chromatographed with a Hex-AcOEt mixture $(5: 1) .{ }^{1} \mathrm{H}$ NMR $\left(\mathrm{CDCl}_{3}, 300 \mathrm{MHz}\right): \delta_{\mathrm{H}} 0.89(\mathrm{t}, 3 \mathrm{H}, J=6.9 \mathrm{~Hz}), 1.39-1.26$ (m, 14H), 1.69-1.59 (m, 4H), 2.07-2.01 (m, 3H), $2.25(\mathrm{t}, 2 \mathrm{H}, J=$ $7.4 \mathrm{~Hz}$ ), 2.77 (t, 2H, $=6.9 \mathrm{~Hz}), 3.91-3.87(\mathrm{~m}, 2 \mathrm{H}), 5.07$ (q, 1H, $=6.2 \mathrm{~Hz}), 5.41-5.29(\mathrm{~m}, 3 \mathrm{H}), 6.1(\mathrm{~m}, \mathrm{~d}, J=6.6 \mathrm{~Hz}), 7.41-7.27$ $(\mathrm{m}, 5 \mathrm{H}) .{ }^{13} \mathrm{C} \mathrm{NMR}\left(\mathrm{CDCl}_{3}, 75 \mathrm{MHz}\right): \delta_{\mathrm{C}} 14.2,22.7,25.7,25.8$, 27.3, 29.3, 29.4, 29.4, 29.4, 29.7, 31.6, 36.8, 55.9, 66.5, 126.8, 127.9, 128.0, 128.2, 128.9, 130.1, 130.3, 139.3, 174.1.

(9Z,12Z)- $\mathrm{N}$-(2-Phenylpropan-2-yl)-octadeca-9,12-dienamide

(2e). (9Z,12Z)- $N$-(2-Phenylpropan-2-yl)-octadeca-9,12-dienamide (2e) was obtained from $(9 Z, 12 Z)$-octadeca-9,12-dienoyl chloride (658 $\mathrm{mg}, 2.21 \mathrm{mmol}$ ) and 1-methyl-1-phenyl ethylamine (300 $\mathrm{mg}, 2.21 \mathrm{mmol}) .704 \mathrm{mg}$ of the synthetic macamide $2 \mathrm{e}(80 \%$ yield) were obtained as a yellowish liquid. The product was chromatographed with a Hex-AcOEt mixture (7:1). $300 \mathrm{mg}$ of the amine were introduced and $704 \mathrm{mg}$ of product were obtained (80\% yield). ${ }^{1} \mathrm{H}$ NMR $\left(\mathrm{CDCl}_{3}, 300 \mathrm{MHz}\right): \delta_{\mathrm{H}} 0.89(\mathrm{t}$, $3 \mathrm{H}, J=7.9 \mathrm{~Hz}), 1.39-1.25(\mathrm{~m}, 14 \mathrm{H}), 1.66-1.56(\mathrm{~m}, 4 \mathrm{H}), 1.70(\mathrm{~s}$, $6 \mathrm{H}), 2.08-2.02(\mathrm{~m}, 3 \mathrm{H}), 2.14(\mathrm{t}, 2 \mathrm{H}, J=7.4 \mathrm{~Hz}), 2.77(\mathrm{t}, 1 \mathrm{H}, J=$ $5.9 \mathrm{~Hz}), 5.39-5.29(\mathrm{~m}, 4 \mathrm{H}), 5.66$ (bs, $1 \mathrm{H}), 7.41-7.19(\mathrm{~m}, 5 \mathrm{H}) .{ }^{13} \mathrm{C}$ $\mathrm{NMR}\left(\mathrm{CDCl}_{3}, 75 \mathrm{MHz}\right): \delta_{\mathrm{C}} 14.1,22.6,25.7,25.8,27.2,29.2,29.2$, 29.3, 29.3, 29.4, 29.7, 31.5, 37.3, 55.7, 124.8, 126.5, 128.0, 128.1, 128.3, 130.1, 130.2, 147.1, 172.5 .

(9Z,12Z)- $N$-Benzyl- $N$-methyloctadeca-9,12-dienamide (2f). (9Z,12Z)- $N$-Benzyl- $N$-methyloctadeca-9,12-dienamide (2f) was obtained from $(9 Z, 12 Z)$-octadeca-9,12-dienoyl chloride (572 $\mathrm{mg}, 1.92 \mathrm{mmol}$ ) and $\mathrm{N}$-benzyl methylamine (233 mg, 1.92 mmol). $477 \mathrm{mg}$ of the synthetic macamide $2 \mathrm{f}$ (65\% yield) were obtained as a yellowish liquid. The product was chromatographed with a Hex-AcOEt mixture (4:1). ${ }^{1} \mathrm{H}$ NMR $\left(\mathrm{CDCl}_{3}, 300 \mathrm{MHz}\right): \delta_{\mathrm{H}} 0.89(\mathrm{t}, 3 \mathrm{H}, J=7.0 \mathrm{~Hz}), 1.36-1.25(\mathrm{~m}$, $14 \mathrm{H}), 1.49$ (d, 3H, $J=6.9 \mathrm{~Hz}), 1.65-1.56(\mathrm{~m}, 4 \mathrm{H}), 2.04-2.00$ $(\mathrm{m}, 4 \mathrm{H}), 2.16(\mathrm{t}, 2 \mathrm{H}, J=7.8 \mathrm{~Hz}) 2.77(\mathrm{t}, 2 \mathrm{H}, J=5.9 \mathrm{~Hz}), 2.88$ (s, 3H), 4.56 (s, 2H), 5.43-5.29 (m, 4H), 5.61 (bd, 1H), 7.36$7.15(\mathrm{~m}, 5 \mathrm{H}) .{ }^{13} \mathrm{C} \mathrm{NMR}\left(\mathrm{CDCl}_{3}, 75 \mathrm{MHz}\right): \delta_{\mathrm{C}} 14.1,21.8,22.6$, 25.7, 25.8, 27.2, 29.2, 29.3, 29.3, 29.4, 29.6, 31.5, 36.8, 50.6, 126.2, 127.8, 127.9, 128.4, 128.6, 129.9, 130.2, 137.4, 173.3.

(9Z,12Z)-1-(Benzyloxy)-octadeca-9,12-dien-1-olate (9Z,12Z)-1-(Benzyloxy)-octadeca-9,12-dien-1-olate (2g) was obtained from $(9 Z, 12 Z)$-octadeca-9,12-dienoyl chloride (581 $\mathrm{mg}, 1.94 \mathrm{mmol}$ ) and benzyl alcohol (200 mg, $1.94 \mathrm{mmol}) .640$ $\mathrm{mg}$ of the synthetic macamide $2 \mathrm{~g}$ ( $80 \%$ yield) were obtained as a yellowish liquid. The product was chromatographed with a Hex-AcOEt mixture $(4: 1) .{ }^{1} \mathrm{H}$ NMR $\left(\mathrm{CDCl}_{3}, 300 \mathrm{MHz}\right): \delta_{\mathrm{H}}$ $0.90(\mathrm{t}, 3 \mathrm{H}, J=6.9 \mathrm{~Hz}), 1.38-1.27(\mathrm{~m}, 14 \mathrm{H}), 1.70-1.60(\mathrm{~m}, 2 \mathrm{H})$, 2.11-2.01 (m, 4H), $2.36(\mathrm{t}, 2 \mathrm{H}, J=7.6 \mathrm{~Hz}), 2.78(\mathrm{t}, 2 \mathrm{H}, J=5.9$ $\mathrm{Hz}), 5.12(\mathrm{~s}, 2 \mathrm{H}), 5.40-5.30(\mathrm{~m}, 4 \mathrm{H}), 7.38-7.35(\mathrm{~m}, 5 \mathrm{H}) .{ }^{13} \mathrm{C}$ NMR $\left(\mathrm{CDCl}_{3}, 75 \mathrm{MHz}\right): \delta_{\mathrm{C}} 14.1,22.6,25.0,25.7,29.1,29.2$, 29.4, 29.6, 31.6, 34.3, 66.0, 128.0, 128.1, 128.1, 128.2, 128.5, 130.0, 130.2, 136.2, 173.5 HRESIMS $[\mathrm{M}+\mathrm{Na}]^{+} \mathrm{m} / z 425.2633$ (calculated for $\mathrm{C}_{25} \mathrm{H}_{32} \mathrm{O}_{2} \mathrm{Na} 393.2764$ ).

(9Z,12Z)-1-(Benzylthio)-octadeca-9,12-dien-1-olate

(2h). (9Z,12Z)-1-(Benzylthio)-octadeca-9,12-dien-1-olate (2h) was obtained from $(9 Z, 12 Z)$-octadeca-9,12-dienoyl chloride (357 $\mathrm{mg}, 1.20 \mathrm{mmol}$ ) and benzyl mercaptan (150 mg, $1.20 \mathrm{mmol})$. $355 \mathrm{mg}$ of the synthetic macamide $\mathbf{2 h}$ (76\% yield) were obtained as a yellowish liquid. The product was chromatographed with a Hex-AcOEt mixture $(4: 1) .{ }^{1} \mathrm{H}$ NMR $\left(\mathrm{CDCl}_{3}, 300 \mathrm{MHz}\right): \delta_{\mathrm{H}} 0.88(\mathrm{t}, 3 \mathrm{H}, J=6.9 \mathrm{~Hz}), 1.29(\mathrm{~m}, 14 \mathrm{H})$, $1.64(\mathrm{~m}, 2 \mathrm{H}), 2.02(\mathrm{~m}, 4 \mathrm{H}), 2.54(\mathrm{t}, 2 \mathrm{H}, J=7.7 \mathrm{~Hz}), 2.76(\mathrm{t}$, $2 \mathrm{H}, J=5.9 \mathrm{~Hz}), 4.10(\mathrm{~s}, 2 \mathrm{H}), 5.38-5.25(\mathrm{~m}, 4 \mathrm{H}), 7.33-7.23(\mathrm{~m}$, $5 \mathrm{H}){ }^{13} \mathrm{C} \mathrm{NMR}\left(\mathrm{CDCl}_{3}, 75 \mathrm{MHz}\right): \delta_{\mathrm{C}} 14.1,22.6,25.6,25.7,27.2$, 27.3, 28.9, 29.1, 29.2, 29.4, 29.6, 31.6, 33.1, 43.8, 127.2, 128.0, 128.1, 128.6, 128.8, 130.0, 130.2, 137.8, 198.6.

$(9 Z, 12 Z)-N$-(1-Phenylethyl)-octadeca-9,12-dien-1-amine (2i). (9Z,12Z)- $N$-(1-Phenylethyl)-octadeca-9,12-dien-1-amine (2i) was obtained from derivative $\mathbf{1 f}(150 \mathrm{mg}, 0.40 \mathrm{mmol})$ and $\mathrm{LiAlH}_{4}$ (76 mg, $2 \mathrm{mmol}) .119 \mathrm{mg}$ of the synthetic macamide $2 \mathbf{i}(83 \%$ yield) were obtained as a yellowish liquid. The product was chromatographed with a Hex-AcOEt mixture (1:1). ${ }^{1} \mathrm{H}$ NMR $\left(\mathrm{CDCl}_{3}, 300 \mathrm{MHz}\right): \delta_{\mathrm{H}} 0.85(\mathrm{t}, 3 \mathrm{H}, J=6.9 \mathrm{~Hz}), 1.33-1.20(\mathrm{~m}$, $14 \mathrm{H}), 1.32$ (d, 3H, $J=10.4 \mathrm{~Hz}), 2.06-1.96(\mathrm{~m}, 4 \mathrm{H}), 2.49-2.34$ $(\mathrm{m}, 2 \mathrm{H}), 2.73(\mathrm{t}, 2 \mathrm{H}, J=5.8 \mathrm{~Hz}), 3.71(\mathrm{q}, 1 \mathrm{H}, J=6.6 \mathrm{~Hz}), 5.41-$ $5.26(\mathrm{~m}, 4 \mathrm{H}), 7.16-7.28(\mathrm{~m}, 5 \mathrm{H}){ }^{13} \mathrm{C} \mathrm{NMR}\left(\mathrm{CDCl}_{3}, 75 \mathrm{MHz}\right): \delta_{\mathrm{C}}$ 14.2, 22.7, 24.4, 25.8, 27.3, 27.3, 27.5, 29.4, 29.5, 29.6, 29.8, $30.4,31.7,48.0,58.5,126.7,126.9,128.1,128.1,128.5,130.2$, 130.3, 146.0. HRESIMS $[\mathrm{M}+\mathrm{H}]^{+} \mathrm{m} / z 370.3468$ (calculated for $\left.\mathrm{C}_{26} \mathrm{H}_{44} \mathrm{~N} 370.3468\right)$.

(9Z,12Z)- $N$-(1-Phenylethyl)-octadeca-9,12-dienothiamide

(2j). $\quad(9 Z, 12 Z)-N$-(1-Phenylethyl)-octadeca-9,12-dienothiamide (2j) was obtained from derivative 1 f $(130 \mathrm{mg}, 0.34 \mathrm{mmol})$ and Lawesson's reagent $(206 \mathrm{mg}, 0.51 \mathrm{mmol}) .135 \mathrm{mg}$ of the synthetic macamide $\mathbf{2 \mathbf { j }}(99 \%$ yield) were obtained as a yellowish liquid. The product was chromatographed with a 
Hex-AcOEt mixture (15:1). ${ }^{1} \mathrm{H}$ NMR $\left(\mathrm{CDCl}_{3}, 300 \mathrm{MHz}\right): \delta_{\mathrm{H}}$ $0.83(\mathrm{t}, 3 \mathrm{H}, J=6.9 \mathrm{~Hz}), 1.32-1.18(\mathrm{~m}, 14 \mathrm{H}), 1.50(\mathrm{~d}, 3 \mathrm{H}, J=$ $6.9 \mathrm{~Hz}), 1.72-1.62(\mathrm{~m}, 2 \mathrm{H}), 2.03-1.93(\mathrm{~m}, 2 \mathrm{H}), 2.54(\mathrm{t}, 2 \mathrm{H}, J=$ $7.8 \mathrm{~Hz}), 2.71(\mathrm{t}, 2 \mathrm{H}, J=5.9 \mathrm{~Hz}), 5.36-5.25(\mathrm{~m}, 4 \mathrm{H}), 5.70$ (quint, $1 \mathrm{H}, J=7.1 \mathrm{~Hz}), 7.27-7.17(\mathrm{~m}, 5 \mathrm{H}), 7.78(\mathrm{bd}, 1 \mathrm{H}, J=$ 8.0 Hz). ${ }^{13} \mathrm{C} \mathrm{NMR}\left(\mathrm{CDCl}_{3}, 75 \mathrm{MHz}\right): \delta_{\mathrm{C}} 14.0,19.9,22.4,25.5$, 27.1, 28.7, 29.0, 29.1, 29.2, 29.4, 29.5, 31.4, 47.0, 54.2, 126.4, 127.5, 127.8, 127.9, 128.6, 129.8, 130.0, 141.3, 204.2.

(9Z,12Z)- $N$-(1-Cyclohexylethyl)-octadeca-9,12-dienamide

(3a). $\quad(9 Z, 12 Z)-N$-(1-Cyclohexylethyl)-octadeca-9,12-dienamide (3a) was obtained from (9Z,12Z)-octadeca-9,12-dienoyl chloride (187 mg, $0.63 \mathrm{mmol})$ and cyclohexyl ethylamine (80 $\mathrm{mg}, 0.63 \mathrm{mmol}) .178 \mathrm{mg}$ of the synthetic macamide $3 \mathbf{a}(73 \%$ yield) were obtained as a yellowish liquid. The product was chromatographed with a Hex-AcOEt mixture $(5: 1) .{ }^{1} \mathrm{H}$ NMR $\left(\mathrm{CDCl}_{3}, 300 \mathrm{MHz}\right): \delta_{\mathrm{H}} 0.88(\mathrm{t}, 3 \mathrm{H}, J=6.9 \mathrm{~Hz}), 1.29(\mathrm{~m}, 14 \mathrm{H})$, $1.64(\mathrm{~m}, 2 \mathrm{H}), 2.02(\mathrm{~m}, 4 \mathrm{H}), 2.54(\mathrm{t}, 2 \mathrm{H}, J=7.7 \mathrm{~Hz}), 2.76(\mathrm{t}$, $2 \mathrm{H}, J=5.9 \mathrm{~Hz}), 4.10(\mathrm{~s}, 2 \mathrm{H}), 5.38-5.25(\mathrm{~m}, 4 \mathrm{H}), 7.33-7.23(\mathrm{~m}$, $5 \mathrm{H}) .{ }^{13} \mathrm{C} \mathrm{NMR}\left(\mathrm{CDCl}_{3}, 75 \mathrm{MHz}\right): \delta_{\mathrm{C}} 14.2,18.2,22.7,25.8,26.0$, 26.3, 26.3, 26.6, 27.3, 29.2, 29.3, 29.4, 29.4, 29.5, 29.7, 31.7, $37.3,43.2,49.3,128.1,128.2,130.2,130.3,172.4$.

(9Z,12Z)- $N$-(3,3-Dimethylbutan-2-yl)-octadeca-9,12-

dienamide (3b). (9Z,12Z)- $N$-(3,3-Dimethylbutan-2-yl)-octadeca9,12-dienamide (3b) was obtained from $(9 Z, 12 Z)$-octadeca9,12-dienoyl chloride (294 mg, $0.98 \mathrm{mmol}$ ) and 2-amino-3,3dimethylbutane (100 mg, $0.98 \mathrm{mmol}) .310 \mathrm{mg}$ of the synthetic macamide $\mathbf{3 b}$ (77\% yield) were obtained as a yellowish liquid. The product was chromatographed with a Hex-AcOEt mixture (7:1). ${ }^{1} \mathrm{H} \mathrm{NMR}\left(\mathrm{CDCl}_{3}, 300 \mathrm{MHz}\right): \delta_{\mathrm{H}} 0.83(\mathrm{~s}, 3 \mathrm{H}), 0.83(\mathrm{t}, 9 \mathrm{H}$, $J=8.0 \mathrm{~Hz}), 0.98(\mathrm{~d}, 3 \mathrm{H}, J=7.8 \mathrm{~Hz}), 1.24(\mathrm{~m}, 14 \mathrm{H}), 1.57(\mathrm{~m}$, $2 \mathrm{H}), 1.98(\mathrm{q}, 4 \mathrm{H}, J=6.4 \mathrm{~Hz}), 2.11(\mathrm{t}, 2 \mathrm{H}, J=7.9 \mathrm{~Hz}), 2.70(\mathrm{t}$, $2 \mathrm{H}, J=5.9 \mathrm{~Hz}), 3.83(\mathrm{~m}, 1 \mathrm{H}), 5.30(\mathrm{~m}, 4 \mathrm{H}), 5.52(\mathrm{bd}, 1 \mathrm{H}, J=$ $9.5 \mathrm{~Hz}) .{ }^{13} \mathrm{C} \mathrm{NMR}\left(\mathrm{CDCl}_{3}, 75 \mathrm{MHz}\right): \delta_{\mathrm{C}} 14.0,16.2,22.6,25.6$, 26.0, 26.2, 27.2, 29.3, 29.3, 29.3, 29.6, 31.5, 34.1, 37.1, 52.4, $127.9,128.0,130.0,130.1,172.3$.

$(9 Z, 12 Z)-N$-(1-((3r,5r,7r)-Adamantan-1-yl)-ethyl)-octadeca9,12-dienamide (3c). (9Z,12Z)- $N$-(1-((3r,5r,7r)-Adamantan-1-yl)ethyl)-octadeca-9,12-dienamide (3c) was obtained from (9Z,12Z)-octadeca-9,12-dienoyl chloride (250 mg, $0.84 \mathrm{mmol}$ ) and 1-adamantylamine (150 $\mathrm{mg}, 0.84 \mathrm{mmol}) .240 \mathrm{mg}$ of the synthetic macamide 3c $(65 \%$ yield $)$ were obtained as a yellowish liquid. The product was chromatographed with a Hex-AcOEt mixture (7:1). ${ }^{1} \mathrm{H}$ NMR $\left(\mathrm{CDCl}_{3}, 300 \mathrm{MHz}\right): \delta_{\mathrm{H}} 0.88$ $(\mathrm{t}, 3 \mathrm{H}, J=6.8 \mathrm{~Hz}), 1.00(\mathrm{~d}, 3 \mathrm{H}, J=6.9 \mathrm{~Hz}), 1.42-1.25(\mathrm{~m}, 14 \mathrm{H})$, 1.60-1.40 (m, 6H), 1.75-1.57 (m, 8H), 2.10-1.93 (m, 6H), 2.16 $(\mathrm{t}, 2 \mathrm{H}, J=7.8 \mathrm{~Hz}), 2.77(\mathrm{t}, 2 \mathrm{H}, J=5.9 \mathrm{~Hz}), 3.77-3.67(\mathrm{~m}, 1 \mathrm{H})$, 5.42-5.22 (m, 4H). ${ }^{13} \mathrm{C} \mathrm{NMR}\left(\mathrm{CDCl}_{3}, 75 \mathrm{MHz}\right): \delta_{\mathrm{C}} 14.2,14.8$, 22.7, 25.8, 26.1, 27.3, 28.5, 29.3, 29.4, 29.5, 29.5, 29.8, 31.7, $35.9,37.2,37.4,38.6,52.8,128.1,128.2,130.2,130.4,172.5$.

(9Z,12Z)- $N$-(1-(4-Hydroxyphenyl)-ethyl)-octadeca-9,12-

dienamide (3d). (9Z,12Z)- $N$-(1-(4-Hydroxyphenyl)-ethyl)octadeca-9,12-dienamide (3d) was obtained from $(9 Z, 12 Z)$ octadeca-9,12-dienoyl chloride (271 mg, $0.91 \mathrm{mmol})$ and 1-(4hydroxyphenyl)-ethylamine (125 mg, $0.91 \mathrm{mmol}) .251 \mathrm{mg}$ of the synthetic macamide $\mathbf{3 d}$ (69\% yield) were obtained as a yellowish liquid. The product was chromatographed with a
Hex-AcOEt mixture (4:1). ${ }^{1} \mathrm{H}$ NMR $\left(\mathrm{CDCl}_{3}, 300 \mathrm{MHz}\right): \delta_{\mathrm{H}} 0.89$ $(\mathrm{t}, 3 \mathrm{H}, J=6.8 \mathrm{~Hz}), 1.44-4.17(\mathrm{~m}, 14 \mathrm{H}), 1.47(\mathrm{~d}, 3 \mathrm{H}, J=6.9$ $\mathrm{Hz}), 1.66-1.58(\mathrm{~m}, 2 \mathrm{H}), 1.79-1.70(\mathrm{~m}, 2 \mathrm{H}), 2.11-2.02(\mathrm{~m}, 4 \mathrm{H})$, $2.15(\mathrm{t}, 2 \mathrm{H}, J=7.9 \mathrm{~Hz}), 2.54(\mathrm{t}, 2 \mathrm{H}, J=7.6 \mathrm{~Hz}), 2.82-2.74(\mathrm{~m}$, $4 \mathrm{H}$ ), 5.16 (quint, $1 \mathrm{H}, J=7.3 \mathrm{~Hz}$ ), 5.44-5.28 (m, 4H), 5.61 (bd, $1 \mathrm{H}, J=7.9 \mathrm{~Hz}), 7.03(\mathrm{~d}, 2 \mathrm{H}, J=8.6 \mathrm{~Hz}), 7.32(\mathrm{~d}, 2 \mathrm{H}, J=8.6$ $\mathrm{Hz}) .{ }^{13} \mathrm{C} \mathrm{NMR}\left(\mathrm{CDCl}_{3}, 75 \mathrm{MHz}\right): \delta_{\mathrm{C}} 14.2,22.7,25.8,27.3,29.2$, 29.2, 29.3, 29.3, 29.4, 29.5, 29.7, 31.7, 121.9, 127.5, 128.1, 128.2, 130.2, 130.4, 140.8, 150.0, 172.2.

\section{$(9 Z, 12 Z)-N$-(1-(4-Methoxyphenyl)-ethyl)-octadeca-9,12-}

dienamide (3e). (9Z,12Z)- $N$-(1-(4-Methoxyphenyl)-ethyl)octadeca-9,12-dienamide (3e) was obtained from $(9 Z, 12 Z)$ octadeca-9,12-dienoyl chloride (197 mg, $0.66 \mathrm{mmol}$ ) and 1-(4methoxyphenyl)-ethylamine (100 mg, $0.66 \mathrm{mmol}) .226 \mathrm{mg}$ of the synthetic macamide $3 \mathbf{e}(83 \%$ yield) were obtained as a yellowish liquid. ${ }^{1} \mathrm{H} \mathrm{NMR}\left(\mathrm{CDCl}_{3}, 300 \mathrm{MHz}\right): \delta_{\mathrm{H}} 0.87(\mathrm{t}, 3 \mathrm{H}, J=$ $7.0 \mathrm{~Hz}), 1.40-1.27$ (m, 14H), 1.42 (d, 3H, $J=7.0 \mathrm{~Hz}), 1.54-1.61$ $(\mathrm{m}, 2 \mathrm{H}), 2.02-2.10(\mathrm{~m}, 4 \mathrm{H}), 2.15(\mathrm{t}, 2 \mathrm{H}, J=7.8 \mathrm{~Hz}), 2.75(\mathrm{t}, 2 \mathrm{H}$, $J=5.9 \mathrm{~Hz}$ ), $3.74(\mathrm{~s}, 3 \mathrm{H}), 5.05$ (quint, $1 \mathrm{H}, J=10.7 \mathrm{~Hz}$ ), $5.44-$ $5.32(\mathrm{~m}, 4 \mathrm{H}), 6.12(\mathrm{bd}, 1 \mathrm{H}, J=7.9 \mathrm{~Hz}), 6.82(\mathrm{~d}, 2 \mathrm{H}, J=8.7 \mathrm{~Hz})$, $7.20(\mathrm{~d}, 2 \mathrm{H}, J=8.7 \mathrm{~Hz}) .{ }^{13} \mathrm{C} \mathrm{NMR}\left(\mathrm{CDCl}_{3}, 75 \mathrm{MHz}\right): \delta_{\mathrm{C}} 14.0$, 21.7, 22.5, 25.6, 25.8, 27.2, 29.1, 29.3, 29.3, 29.3, 29.6, 31.5, 36.8, 47.9, 55.2, 113.9, 127.3, 130.0, 130.2, 135.6, 158.7, 172.2.

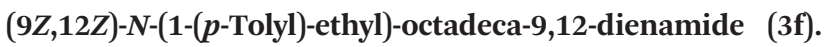
(9Z,12Z)- $N$-(1-( $p$-Tolyl)-ethyl)-octadeca-9,12-dienamide (3f) was obtained from $(9 Z, 12 Z)$-octadeca-9,12-dienoyl chloride (289 $\mathrm{mg}, 0.97 \mathrm{mmol}$ ) and 1-(4-methylphenyl)-ethylamine (130 mg, $0.97 \mathrm{mmol}$ ). $331 \mathrm{mg}$ of the synthetic macamide $3 \mathrm{f}$ ( $80 \%$ yield) were obtained as a yellowish liquid. The product was chromatographed with a Hex-AcOEt mixture (6:1). ${ }^{1} \mathrm{H}$ NMR $\left(\mathrm{CDCl}_{3}, 300 \mathrm{MHz}\right): \delta_{\mathrm{H}} 0.90(\mathrm{t}, 3 \mathrm{H}, J=6.9 \mathrm{~Hz}), 1.25-1.40(\mathrm{~m}$, $14 \mathrm{H}), 1.45(\mathrm{~d}, 3 \mathrm{H}, J=6.9 \mathrm{~Hz}), 1.66-1.58(\mathrm{~m}, 2 \mathrm{H}), 2.01-2.08$ $(\mathrm{m}, 4 \mathrm{H}), 2.15(\mathrm{t}, 2 \mathrm{H}, J=8.0 \mathrm{~Hz}), 2.32(\mathrm{~s}, 3 \mathrm{H}), 2.78(\mathrm{t}, 2 \mathrm{H}, J=$ $5.9 \mathrm{~Hz}$ ), 5.10 (quint, $1 \mathrm{H}, J=7.0 \mathrm{~Hz}$ ), 5.27-5.43 (m, 4H), 6.02 (bd, $J=7.8 \mathrm{~Hz}$ ), $7.12(\mathrm{~d}, 2 \mathrm{H}, J=8.0 \mathrm{~Hz}), 7.20(\mathrm{~d}, 2 \mathrm{H}, J=8.1$ $\mathrm{Hz}){ }^{13} \mathrm{C} \mathrm{NMR}\left(\mathrm{CDCl}_{3}, 75 \mathrm{MHz}\right): \delta_{\mathrm{C}} 14.1,21.04,21.8,22.6$, 25.7, 25.8, 27.2, 29.2, 29.3, 29.31, 29.4, 31.6, 36.8, 48.3, 126.1, 128.0, 128.1, 129.3, 130.1, 130.2, 136.8, 140.5, 172.2.

$(9 Z, 12 Z)-N$-(1-(4-(Trifluoromethyl)-phenyl)-ethyl)-octadeca9,12-dienamide (3g). (9Z,12Z)- $N$-(1-(4-(Trifluoromethyl)phenyl)-ethyl)-octadeca-9,12-dienamide (3g) was obtained from $(9 Z, 12 Z)$-octadeca-9,12-dienoyl chloride (141 mg, 0.47 $\mathrm{mmol}$ ) and 1-(4-trifluoromethylphenyl)-ethylamine $(90 \mathrm{mg}$, $0.47 \mathrm{mmol}) .156 \mathrm{mg}$ of the synthetic macamide $3 \mathrm{~g}$ (73\% yield) were obtained as a yellowish liquid. The product was chromatographed with a Hex-AcOEt mixture (6:1). ${ }^{1} \mathrm{H}$ NMR $\left(\mathrm{CDCl}_{3}, 300 \mathrm{MHz}\right): \delta_{\mathrm{H}} 0.88(\mathrm{t}, 3 \mathrm{H}, J=6.8 \mathrm{~Hz}), 1.25-1.40(\mathrm{~m}$, $14 \mathrm{H}), 1.48(\mathrm{~d}, 3 \mathrm{H}, J=6.9 \mathrm{~Hz}), 1.66-1.58(\mathrm{~m}, 2 \mathrm{H}), 2.01-2.08$ $(\mathrm{m}, 4 \mathrm{H}), 2.18(\mathrm{t}, 3 \mathrm{H}, J=8.1 \mathrm{~Hz}), 2.77(\mathrm{t}, 2 \mathrm{H}, J=6.2 \mathrm{~Hz}), 5.17$ (quint, $1 \mathrm{H}, J=7.2 \mathrm{~Hz}), 5.27-5.43(\mathrm{~m}, 4 \mathrm{H}), 5.74(\mathrm{bd}, 1 \mathrm{H}, J=$ $7.1 \mathrm{~Hz}), 7.41$ (d, $2 \mathrm{H}, J=8.1 \mathrm{~Hz}), 7.58(\mathrm{~d}, 2 \mathrm{H}, J=8.1 \mathrm{~Hz}) .{ }^{13} \mathrm{C}$ NMR $\left(\mathrm{CDCl}_{3}, 75 \mathrm{MHz}\right): \delta_{\mathrm{C}} 14.2,22.0,22.7,25.8,25.8,27.3$, $27.3,25.8,25.8,29.3,29.4,29.5,29.7,31.7,36.9,48.5,175.7$ (q, $J=3.7 \mathrm{~Hz}), 126.6,128.0,128.2,130.1,130.1,130.4$.

(9Z,12Z)-N-(1-(4-Fluorophenyl)-ethyl)-octadeca-9,12dienamide (3h). (9Z,12Z)-N-(1-(4-Fluorophenyl)-ethyl)-octadeca- 
9,12-dienamide (3h) was obtained from (9Z,12Z)-octadeca-9,12dienoyl chloride (246 mg, $0.82 \mathrm{mmol}$ ) and 4-fluoro- $\alpha$-methyl benzylamine (115 mg, $0.82 \mathrm{mmol}$ ). $255 \mathrm{mg}$ of the synthetic macamide $3 \mathbf{h}$ (79\% yield) were obtained as a yellowish liquid. The product was chromatographed with a Hex-AcOEt mixture (3:1). ${ }^{1} \mathrm{H} \mathrm{NMR}\left(\mathrm{CDCl}_{3}, 300 \mathrm{MHz}\right): \delta_{\mathrm{H}} 0.89(\mathrm{t}, 3 \mathrm{H}, J=6.7 \mathrm{~Hz})$, 1.42-1.25 (m, 14H), 1.45 (d, 3H, $J=6.9 \mathrm{~Hz}), 1.54-1.61(\mathrm{~m}, 2 \mathrm{H})$, 2.04-2.10 (m, 4H), $2.16(\mathrm{t}, 2 \mathrm{H}, J=8.1 \mathrm{~Hz}), 2.16(\mathrm{t}, 2 \mathrm{H}, J=8.1$ $\mathrm{Hz}$ ), 2.77 (t, $2 \mathrm{H}, J=6.1 \mathrm{~Hz}$ ), 5.11 (quint, $1 \mathrm{H}, J=7.2 \mathrm{~Hz}$ ), $5.42-$ 5.34 (m, 4H), 5.92 (bd, 1H), 6.9-7.1 (m, 2H), 7.26-7.36 (m, 2H). ${ }^{13} \mathrm{C} \mathrm{NMR}\left(\mathrm{CDCl}_{3}, 75 \mathrm{MHz}\right): \delta_{\mathrm{C}} 14.1,21.9,22.7,25.7,25.8,27.3$, $29.2,29.3,29.3,29.4,29.7,31.6,36.9,48.0,115.5$ (d, $J=79.9$ $\mathrm{Hz}), 127.9$ (d, $J=8.0 \mathrm{~Hz}), 128.1$ (d, $J=12.5 \mathrm{~Hz}), 130.2$ (d, $J=$ 16.0 Hz), 139.3 (d, $J=3.1 \mathrm{~Hz}), 162.1$ (d, $J=245.4 \mathrm{~Hz}), 172.3 .{ }^{19} \mathrm{~F}$ $\mathrm{NMR}\left(\mathrm{CDCl}_{3}, 75 \mathrm{MHz}\right): \delta_{\mathrm{C}}-115.5$.

(9Z,12Z)-N-(1-(4-Bromophenyl)-ethyl)-octadeca-9,12-

dienamide (3i). (9Z,12Z)- $N$-(1-(4-Bromophenyl)-ethyl)-octadeca9,12-dienamide (3i) was obtained from $(9 Z, 12 Z)$-octadeca-9,12dienoyl chloride (201 mg, $0.67 \mathrm{mmol}$ ) and 4-bromo- $\alpha$-methyl benzylamine (135 mg, $0.67 \mathrm{mmol}) .255 \mathrm{mg}$ of the synthetic macamide $3 \mathbf{i}$ ( $82 \%$ yield) were obtained as a yellowish liquid. The product was chromatographed with a Hex-AcOEt mixture (4:1). ${ }^{1} \mathrm{H} \mathrm{NMR}\left(\mathrm{CDCl}_{3}, 300 \mathrm{MHz}\right): \delta_{\mathrm{H}} 0.87(\mathrm{t}, 3 \mathrm{H}, J=4.9 \mathrm{~Hz})$, $1.42-1.25(\mathrm{~m}, 14 \mathrm{H}), 1.45$ (d, 3H, $J=7.0 \mathrm{~Hz}), 1.56-1.61(\mathrm{~m}, 2 \mathrm{H})$, $2.05(\mathrm{q}, 4 \mathrm{H}, J=6.4 \mathrm{~Hz}), 2.12(\mathrm{t}, 2 \mathrm{H}, J=8.1 \mathrm{~Hz}), 2.75(\mathrm{t}, 2 \mathrm{H}, J=$ $5.9 \mathrm{~Hz}$ ), 5.00 (quint, $1 \mathrm{H}, J=7.3 \mathrm{~Hz}$ ), 5.42-5.32 (m, 4H), 6.45 (bd, $1 \mathrm{H}, J=7.8 \mathrm{~Hz}$ ), 7.12 (d, 2H, $J=8.4 \mathrm{~Hz}$ ), 7.38 (d, 2H, $J=8.4$ $\mathrm{Hz}) .{ }^{13} \mathrm{C} \mathrm{NMR}\left(\mathrm{CDCl}_{3}, 75 \mathrm{MHz}\right): \delta_{\mathrm{C}} 14.1,21.7,22.6,25.6,25.8$, 27.2, 29.2, 29.3, 29.3, 29.3, 29.6, 31.5, 36.6, 48.0, 120.9, 128.0, $127.9,128.1,130.0,130.2,131.5,142.8,172.4$.

(9Z,12Z)- $N$-(1-(4-Ethylphenyl)-ethyl)-octadeca-9,12-

dienamide (3j). (9Z,12Z)- $N$-(1-(4-Ethylphenyl)-ethyl)-octadeca9,12-dienamide (3j) was obtained from $(9 Z, 12 Z)$-octadeca9,12-dienoyl chloride (159 $\mathrm{mg}, 0.53 \mathrm{mmol})$ and 1-(4ethylphenyl)-ethylamine ( $80 \mathrm{mg}, 0.53 \mathrm{mmol}$ ). $157 \mathrm{mg}$ of the synthetic macamide $\mathbf{3} \mathbf{j}$ (73\% yield) were obtained as a yellowish liquid. The product was chromatographed with a Hex-AcOEt mixture $(4: 1) .{ }^{1} \mathrm{H}$ NMR $\left(\mathrm{CDCl}_{3}, 300 \mathrm{MHz}\right): \delta_{\mathrm{H}} 0.89$ $(\mathrm{t}, 3 \mathrm{H}, J=6.8 \mathrm{~Hz}), 1.23(\mathrm{t}, 3 \mathrm{H}, J=7.6 \mathrm{~Hz}), 1.40-1.26(\mathrm{~m}, 14 \mathrm{H})$, $1.47(\mathrm{~d}, 3 \mathrm{H}, J=6.9 \mathrm{~Hz}), 1.68-1.59(\mathrm{~m}, 2 \mathrm{H}), 2.06(\mathrm{~m}, 4 \mathrm{H}), 2.15$ $(\mathrm{t}, 2 \mathrm{H}, J=7.9 \mathrm{~Hz}), 2.63(\mathrm{q}, 2 \mathrm{H}, J=7.6 \mathrm{~Hz}), 2.77(\mathrm{t}, 2 \mathrm{H}, J=5.7$ $\mathrm{Hz}$ ), 2.12 (quint, $1 \mathrm{H}, J=7.0 \mathrm{~Hz}$ ), 5.47-5.28 (m, 4H), 5.63 (bd, $1 \mathrm{H}, J=7.9 \mathrm{~Hz}$ ), $7.17(\mathrm{~d}, 2 \mathrm{H}, J=8.1 \mathrm{~Hz}), 7.25(\mathrm{~d}, 2 \mathrm{H}, J=8.1$ $\mathrm{Hz}) .{ }^{13} \mathrm{C} \mathrm{NMR}\left(\mathrm{CDCl}_{3}, 75 \mathrm{MHz}\right): \delta_{\mathrm{C}} 13.8,15.2,21.3,22.3,25.4$, 25.4, 26.9, 28.2, 28.9, 29.0, 29.1, 29.3, 31.2, 36.7, 48.0, 126.0, $127.6,127.8,127.8,129.8,130.0,140.2,143.1,171.8$.

$(\mathbf{9 Z , 1 2 Z )}-\mathrm{N}$-(1-(o-Tolyl)-ethyl)-octadeca-9,12-dienamide (3k). (9Z,12Z)-N-(1-(o-Tolyl)-ethyl)-octadeca-9,12-dienamide (3k) was obtained from $(9 Z, 12 Z)$-octadeca-9,12-dienoyl chloride $(176 \mathrm{mg}$, $0.59 \mathrm{mmol}$ ) and $o$-tolyl ethylamine ( $80 \mathrm{mg}, 0.59 \mathrm{mmol}) .162 \mathrm{mg}$ of the synthetic macamide $3 \mathbf{k}$ were obtained (77\% yield) as a yellowish liquid. The product was chromatographed with a Hex-AcOEt mixture (7:1). ${ }^{1} \mathrm{H}$ NMR $\left(\mathrm{CDCl}_{3}, 300 \mathrm{MHz}\right): \delta_{\mathrm{H}} 0.97$ $(\mathrm{t}, 3 \mathrm{H}, J=6.7 \mathrm{~Hz}), 1.46-1.34(\mathrm{~m}, 14 \mathrm{H}), 1.55(\mathrm{~d}, 3 \mathrm{H}, J=6.8 \mathrm{~Hz})$, 1.73-1.66 (m, 2H), 2.16-2.10 (m, 2H), $2.22(\mathrm{t}, 2 \mathrm{H}, J=8.1 \mathrm{~Hz})$, $2.46(\mathrm{~s}, 3 \mathrm{H}), 2.85(\mathrm{t}, 2 \mathrm{H}, J=6.0 \mathrm{~Hz}), 5.52-5.36(\mathrm{~m}, 4 \mathrm{H}), 5.69(\mathrm{bd}$,
$1 \mathrm{H}, J=8.0 \mathrm{~Hz}), 7.40-7.22(\mathrm{~m}, 4 \mathrm{H}) .{ }^{13} \mathrm{C} \mathrm{NMR}\left(\mathrm{CDCl}_{3}, 75 \mathrm{MHz}\right)$ : $\delta_{\mathrm{C}} 14.2,19.3,21.2,22.7,25.8,25.9,29.3,29.4,29.5,29.7,31.7$, 36.9, 45.3, 124.8, 126.4, 127.4, 128.0, 128.2, 130.2, 130.4, 130.9, 136.2, 141.3, 172.1.

$(9 Z, 12 Z)-N$-(1-(m-Tolyl)-ethyl)-octadeca-9,12-dienamide (31). (9Z,12Z)- $N$-(1-( $m$-Tolyl)-ethyl)-octadeca-9,12-dienamide (3l) was obtained from $(9 Z, 12 Z)$-octadeca-9,12-dienoyl chloride (176 $\mathrm{mg}, 0.59 \mathrm{mmol}$ ) and $m$-tolyl ethylamine ( $80 \mathrm{mg}, 0.59 \mathrm{mmol})$. $162 \mathrm{mg}$ of the synthetic macamide 31 (77\% yield) were obtained as a yellowish liquid. The product was chromatographed with a Hex-AcOEt mixture $(7: 1) .{ }^{1} \mathrm{H}$ NMR $\left(\mathrm{CDCl}_{3}, 300 \mathrm{MHz}\right): \delta_{\mathrm{H}} 0.89(\mathrm{t}, 3 \mathrm{H}, J=6.9 \mathrm{~Hz}), 1.41-1.25(\mathrm{~m}$, $14 \mathrm{H}), 1.45(\mathrm{~d}, 2 \mathrm{H}, J=6.9 \mathrm{~Hz}), 1.63(\mathrm{~m}, 3 \mathrm{H}), 2.08-2.01(\mathrm{~m}$, $4 \mathrm{H}), 2.16(\mathrm{t}, 2 \mathrm{H}, J=7.9 \mathrm{~Hz}), 2.35(\mathrm{~s}, 3 \mathrm{H}), 2.77(\mathrm{t}, 2 \mathrm{H}, J=5.9$ $\mathrm{Hz}$ ), 5.10 (quint, $1 \mathrm{H}, J=7.2 \mathrm{~Hz}$ ), 5.43-5.28 (m, 4H), 5.60 (d, $1 \mathrm{H}, J=7.8 \mathrm{~Hz}), 7.26-7.06(\mathrm{~m}, 4 \mathrm{H}){ }^{13} \mathrm{C} \mathrm{NMR}\left(\mathrm{CDCl}_{3}, 75 \mathrm{MHz}\right)$ : $\delta_{\mathrm{C}} 14.2,21.6,21.9,22.7,25.8,25.9,27.4,29.3,29.4,29.5,29.8$, $31.7,37.1,48.7,123.3,127.2,128.1,128.2$, 128.2, 128.7, 130.2, 130.4, 138.5, 143.4, 172. HRESIMS $[\mathrm{M}+\mathrm{H}]^{+} \mathrm{m} / z 398.3354$ (calculated for $\left.\mathrm{C}_{27} \mathrm{H}_{44} \mathrm{NO} 398.3359\right)$.

(9Z,12Z)- $N$-(1-(3,5-Dimethylphenyl)-ethyl)-octadeca-9,12dienamide (3m). (9Z,12Z)- $N$-(1-(3,5-Dimethylphenyl)-ethyl)octadeca-9,12-dienamide (3m) was obtained from $(9 Z, 12 Z)$ octadeca-9,12-dienoyl chloride (239 $\mathrm{mg}, 0.80 \mathrm{mmol}$ ) and 1-(3,5-dimethylphenyl)-ethylamine (120 mg, $0.80 \mathrm{mmol}) .162$ $\mathrm{mg}$ of the synthetic macamide $3 \mathrm{~m}$ (75\% yield) were obtained as a yellowish liquid. The product was chromatographed with a Hex-AcOEt mixture (7:1). ${ }^{1} \mathrm{H}$ NMR $\left(\mathrm{CDCl}_{3}, 300 \mathrm{MHz}\right): \delta_{\mathrm{H}}$ $0.89(\mathrm{t}, 3 \mathrm{H}, J=6.7 \mathrm{~Hz}), 1.41-1.25(\mathrm{~m}, 14 \mathrm{H}), 1.45(\mathrm{~d}, 2 \mathrm{H}, J=$ $6.9 \mathrm{~Hz}), 1.63(\mathrm{~m}, 2 \mathrm{H}), 2.08-2.01(\mathrm{~m}, 4 \mathrm{H}), 2.15(\mathrm{t}, 2 \mathrm{H}, J=7.9$ $\mathrm{Hz}), 2.24(\mathrm{~s}, 3 \mathrm{H}), 2.26(\mathrm{~s}, 3 \mathrm{H}), 2.77(\mathrm{t}, 2 \mathrm{H}, J=5.9 \mathrm{~Hz}), 5.10$ (quint, $1 \mathrm{H}, J=7.2 \mathrm{~Hz}$ ), 5.43-5.28 (m, 4H), 5.60 (d, 1H, $J=7.8$ $\mathrm{Hz}), 7.12-7.03(\mathrm{~m}, 3 \mathrm{H}){ }^{13} \mathrm{C} \mathrm{NMR}\left(\mathrm{CDCl}_{3}, 75 \mathrm{MHz}\right): \delta_{\mathrm{C}} 14.2$, 19.5, 20.0, 21.9, 22.7, 25.8, 25.9, 27.4, 29.3, 29.4, 29.5, 29.8, $31.7,37.1,48.7,123.6,127.8,128.0,128.2$, 130.0, 130.2, 130.4, 137.0, 140.9, 172.1. HRESIMS $[\mathrm{M}+\mathrm{H}]^{+} \mathrm{m} / z \quad 412.3566$ (calculated for $\left.\mathrm{C}_{28} \mathrm{H}_{46} \mathrm{NO} 412.3574\right)$.

(9Z,12Z)-1-(1-(3,5-Dimethylphenyl)-ethoxy)-octadeca-9,12dien-1-olate (4a). (9Z,12Z)-1-(1-(3,5-Dimethylphenyl)-ethoxy)octadeca-9,12-dien-1-olate (4a) was obtained from $(9 Z, 12 Z)$ octadeca-9,12-dienoyl chloride (139 mg, $0.46 \mathrm{mmol}$ ) and 1-(3,5-dimethylphenyl)-ethan-1-ol (70 mg, $0.46 \mathrm{mmol}) .128$ $\mathrm{mg}$ of the synthetic macamide $\mathbf{4 a}$ ( $80 \%$ yield) were obtained as a yellowish liquid. The product was chromatographed with a Hex-AcOEt mixture (6:1). ${ }^{1} \mathrm{H}$ NMR $\left(\mathrm{CDCl}_{3}, 300 \mathrm{MHz}\right): \delta_{\mathrm{H}}$ $0.89(\mathrm{t}, 3 \mathrm{H}, J=6.7 \mathrm{~Hz}), 1.41-1.25(\mathrm{~m}, 14 \mathrm{H}), 1.45(\mathrm{~d}, 2 \mathrm{H}, J=$ $6.9 \mathrm{~Hz}), 1.63(\mathrm{~m}, 2 \mathrm{H}), 2.08-2.01(\mathrm{~m}, 4 \mathrm{H}), 2.15(\mathrm{t}, 2 \mathrm{H}, J=7.9$ $\mathrm{Hz}), 2.26(\mathrm{~s}, 6 \mathrm{H}), 2.77(\mathrm{t}, 2 \mathrm{H}, J=5.9 \mathrm{~Hz}), 4.08(\mathrm{q}, 1 \mathrm{H}, J=6.9$ $\mathrm{Hz}) 5.10$ (quint, $1 \mathrm{H}, J=7.2 \mathrm{~Hz}$ ), 5.43-5.28 (m, 4H), 5.60 (d, $1 \mathrm{H}, J=7.8 \mathrm{~Hz}), 6.92(\mathrm{~s}, 2 \mathrm{H}), 6.84(\mathrm{~s}, 1 \mathrm{H}) .{ }^{13} \mathrm{C} \mathrm{NMR}\left(\mathrm{CDCl}_{3}, 75\right.$ $\mathrm{MHz}): \delta_{\mathrm{C}} 14.2,19.5,20.0,21.9,22.7,25.8,25.9,27.4,29.3$, 29.4, 29.5, 29.8, 31.7, 37.1, 72.1, 123.8, 127.8, 128.0, 129.5, 130.0, 130.2, 130.4, 138.2, 141.8, 173.1 .

(9Z,12Z)- $N$-(1-(3,5-Dimethylphenyl)-ethyl)-octadeca-9,12dien-1-amine (4b). (9Z,12Z)- $N$-(1-(3,5-Dimethylphenyl)-ethyl)octadeca-9,12-dien-1-amine (4b) was obtained from derivative 
$7 \mathrm{c}(80 \mathrm{mg}, 0.20 \mathrm{mmol})$ and $\mathrm{LiAlH}_{4}(38 \mathrm{mg}, 1 \mathrm{mmol}) .59 \mathrm{mg}$ of the synthetic macamide $\mathbf{4 b}$ (77\% yield) were obtained as a yellowish liquid. The product was chromatographed with a Hex-AcOEt mixture $(1: 1) .{ }^{1} \mathrm{H}$ NMR $\left(\mathrm{CDCl}_{3}, 300 \mathrm{MHz}\right): \delta_{\mathrm{H}} 0.85$ $(\mathrm{t}, 3 \mathrm{H}, J=6.9 \mathrm{~Hz}), 1.33-1.20(\mathrm{~m}, 14 \mathrm{H}), 1.32(\mathrm{~d}, 3 \mathrm{H}, J=10.4$ $\mathrm{Hz}), 2.06-1.96(\mathrm{~m}, 4 \mathrm{H}), 2.49-2.34(\mathrm{~m}, 2 \mathrm{H}), 2.73(\mathrm{t}, 2 \mathrm{H}, J=5.8$ $\mathrm{Hz}), 3.71(\mathrm{q}, 1 \mathrm{H}, J=6.6 \mathrm{~Hz}), 5.41-5.26(\mathrm{~m}, 4 \mathrm{H}), 6.91(\mathrm{~s}, 1 \mathrm{H})$, $7.00(\mathrm{~s}, 2 \mathrm{H}) .{ }^{13} \mathrm{C} \mathrm{NMR}\left(\mathrm{CDCl}_{3}, 75 \mathrm{MHz}\right): \delta_{\mathrm{C}} 14.2,21.5,22.7$, 25.8, 27.3, 27.4, 29.4, 29.5, 29.6, 29.8, 30.4, 31.7, 48.0, 58.7, 124.8, 126.9, 128.1, 128.1, 130.1, 130.3, 130.4, 138.3.

(9Z,12Z)-N-(1-(3,5-Dimethylphenyl)-ethyl)-octadeca-9,12dienethioamide (4c). (9Z,12Z)- $N$-(1-(3,5-Dimethylphenyl)ethyl)-octadeca-9,12-dienethioamide (4c) was obtained from derivative $3 \mathrm{~m}$ (70 $\mathrm{mg}, 0.17 \mathrm{mmol}$ ) and Lawesson's reagent (103 mg, $0.25 \mathrm{mmol}$ ). $62 \mathrm{mg}$ of the synthetic macamide 4c (93\% yield) were obtained as a yellowish liquid. The product was chromatographed with a Hex-AcOEt mixture (15:1). ${ }^{1} \mathrm{H}$ $\mathrm{NMR}\left(\mathrm{CDCl}_{3}, 300 \mathrm{MHz}\right): \delta_{\mathrm{H}} 0.83(\mathrm{t}, 3 \mathrm{H}, J=6.9 \mathrm{~Hz}), 1.32-1.18$ $(\mathrm{m}, 14 \mathrm{H}), 1.50(\mathrm{~d}, 3 \mathrm{H}, J=6.9 \mathrm{~Hz}), 1.72-1.62(\mathrm{~m}, 2 \mathrm{H}), 2.03-1.93$ $(\mathrm{m}, 2 \mathrm{H}), 2.54(\mathrm{t}, 2 \mathrm{H}, J=7.8 \mathrm{~Hz}), 2.71(\mathrm{t}, 2 \mathrm{H}, J=5.9 \mathrm{~Hz}), 5.36-$ $5.25(\mathrm{~m}, 4 \mathrm{H}), 5.70$ (quint, $1 \mathrm{H}, J=7.1 \mathrm{~Hz}), 6.95(\mathrm{~s}, 2 \mathrm{H}), 7.11$ (s, $1 \mathrm{H}) .{ }^{13} \mathrm{C} \mathrm{NMR}\left(\mathrm{CDCl}_{3}, 75 \mathrm{MHz}\right): \delta_{\mathrm{C}} 14.0,19.9,22.4,25.5,27.1$, 28.7, 29.0, 29.1, 29.2, 29.4, 29.5, 31.4, 47.0, 54.2, 124.5, 128.0, 128.2, 129.6, 130.1, 130.4, 138.6, 138.9, 141.4, 204.2.

\subsection{Cell culture}

The THP-1 cell line (human peripheral blood monocyte, TIB202) was used in this study. Cells were grown in specific media according to ATCC recommendations. The incubation condition for the cells was in an atmosphere of 95\% air and $5 \% \mathrm{CO} 2$ at $37{ }^{\circ} \mathrm{C}$. DMEM (Sigma-Aldrich, St. Louis, MO, USA), FBS (Summit Biotechnology; Ft. Collins, CO) and PBS (SAFC Biosciences, Inc. Andover-Hampshire, UK) were used as culture mediums. L-Glutamine was obtained from Applichem. Penicillin and streptomycin were purchased from Fisher Scientific (Pittsburgh, PA). For cytotoxicity and activity assays, the synthetic macamides were dissolved in DMSO (Merck) at a concentration of $10 \mathrm{mM}$.

\subsection{MTT-cytotoxicity assay}

THP-1 cells were seeded in 96-well plates at a density of $5 \times$ $10^{4}$ cells per well and incubated overnight at $37^{\circ} \mathrm{C}$ in a humidified atmosphere of $5 \% \mathrm{CO}_{2}$. Subsequently, cells were treated with test synthetic macamides at the indicated concentrations and DMSO as control for $72 \mathrm{~h}$. An MTT solution (50 $\mu \mathrm{L}, 7 \mathrm{mg} \mathrm{mL}{ }^{-1}$ in PBS) was added to each well, and plates were incubated for an additional $2 \mathrm{~h}$. Next, the medium was removed and $100 \mu \mathrm{L}$ of DMSO was added to each well to dissolve the formazan crystals that were formed. The absorbance was measured at $590 \mathrm{~nm}$ using a spectrophotometric ELISA plate reader (SpectraMax® i3, Molecular Devices, CA, USA). Samples were considered nontoxic for the THP-1 cell line when cell viability was $\geq 90 \%$. Actinomycin D ( $\geq 95 \%$ Sigma-Aldrich, CAS Number 50-76-0) was used as a positive control at a concentration of $0.008 \mu \mathrm{M}$, showing cell death.

\subsection{TNF- $\alpha$ inhibition assay}

THP-1 cell $\left(5 \times 10^{4}\right.$ cells per well $)$ were seeded on a 96-well culture plate and incubated for $12 \mathrm{~h}$. The cells were then pretreated with various concentrations of the synthetic macamides for $2 \mathrm{~h}$, before stimulation with LPS $\left(0.1 \mu \mathrm{g} \mathrm{mL}^{-1}\right)$ with or without synthetic macamides samples for $12 \mathrm{~h}$. Supernatants were then collected and the protein expression levels of TNF- $\alpha$ were measured by using an enzyme-linked immunosorbent assay kit (ELISA), according to the manufacturer's instructions (Diaclone Company, Besancon, France). Absorbance was read at $450 \mathrm{~nm}$ on a spectrophotometric ELISA plate reader (Anthos 2020, Version 2.0.5, Biochrom Ltd., UK). The percentage of TNF- $\alpha$ inhibition was calculated from the ratio between the observed TNF- $\alpha$ amount secreted by treated cells $(\mu \mathrm{M})$ and the baseline secretion of TNF- $\alpha$ (pg mL ${ }^{-1}$ ). C87 (Sigma-Aldrich; 332420-903) was used as positive control at a concentration of $0.11 \mu \mathrm{M}$. Results were normalised to the DMSO solvent control (1\%).

\subsection{Statistical analysis}

$\mathrm{CC}_{50}$ and $\mathrm{IC}_{50}$ values were determined by non-linear regression. All the experiments were performed in triplicate. One-way ANOVA statistical analysis (Tukey's multiple comparisons test, ${ }^{*} p<0.05 ;{ }^{* * *} p<0.001$ ) was performed to evaluate the significant differences among values. All the analysis was performed using GraphPad Prism, version 8.4.0.

\section{Author contribution}

VTP and JAG experimental design of the chemistry study; ARS and LAT contributed to the analysis of the spectral data; LAT and AMS contributed to the conception and experimental design of the pharmacological study and analysis of the measurements of the $\operatorname{clog} P$ values; LAT contributed to the writing and review of the manuscript.

\section{Conflicts of interest}

There are no conflicts to declare.

\section{Acknowledgements}

This work was supported by the Fundación de la Universidad Autónoma de Madrid (FUAM).

\section{References}

1 F. Leulier, L. T. MacNeil, W. J. Lee, J. F. Rawls, P. D. Cani, M. Schwarzer, L. Zhao and S. J. Simpson, Cell Metab., 2017, 25, 522-534, DOI: 10.1016/j.cmet.2017.02.001.

2 L. A. Abdulkhaleq, M. A. Assi, R. Abdullah, M. Zamri-Saad, Y. H. Taufiq-Yap and M. N. M. Hezmee, Vet. World, 2018, 11, 627-635, DOI: 10.14202/vetworld.2018.627-635. 
3 J. M. Zhang and J. An, Int. Anesthesiol. Clin., 2007, 45, 27-37, DOI: 10.1097/AIA.0b013e318034194e.

4 H. Zelová and J. Hošek, Inflammation Res., 2013, 62, 641-651, DOI: 10.1007/s00011-013-0633-0.

5 J. R. Bradley, J. Pathol., 2008, 214, 149-160, DOI: 10.1002/ path.2287.

6 A. F. Belgaumi, M. Al-Bakrah, M. Al-Mahr, A. Al-Jefri, A. AlMusa, M. Saleh, M. F. Salim, M. Osman, L. Osman and H. El-Solh, Cancer, 2003, 97, 2898-2903, DOI: 10.1002/ cncr.11390.

7 L. T. Apaza, V. P. Tena, A. M. Serban, M. J. N. Alonso and A. S. Rumbero, J. Ethnopharmacol., 2019, 235, 199-205, DOI: 10.1016/j.jep.2019.02.015.

8 C. Xia, J. Deng, J. Chen, Y. Zhu, Y. Song, Y. Zhang, H. Li and C. Lin, Rev. Bras. Farmacogn., 2019, 29, 702-709, DOI: 10.1016/j.bjp.2019.05.009.

9 L. T. Apaza, V. P. Tena and P. B. Bermejo, J. Ethnopharmacol., 2020, 247, 112152, DOI: 10.1016/j.jep.2019.112152.

10 J. J. Chen, P. F. Gong, Y. L. Liu, B. Y. Liu, D. Eggert, Y. H. Guo, M. X. Zhao, Q. S. Zhao and B. Zhao, J. Food Sci., 2018, 83, 966-974, DOI: 10.1111/17503841.14083.

11 H. Wu, C. J. Kelley, A. Pino-Figueroa, H. D. Vu and T. J. Maher, Bioorg. Med. Chem., 2013, 21, 5188-5197, DOI: 10.1016/j.bmc.2013.06.034.

12 C. D. A. R. D'Oca, T. Coelho, T. G. Marinho, C. R. Hack, R. D. A. C. Duarte, P. A. da Silva and M. G. D'Oca, Bioorg. Med. Chem. Lett., 2010, 20, 5255-5257, DOI: 10.1016/j. bmcl.2010.06.149.

13 Y. Suzuki, Yakugaku Zasshi, 1977, 97, 5-13, DOI: 10.1248/ yakushi1947.97.1_5.

14 C. de Castellarnau, I. Pich, C. Chanquia, L. Vila, C. Lagunas, J. Fontcuberta and M. Rutllant, Toxicology, 1993, 81, 181-194, DOI: 10.1016/0300-483x(93)90011-g.

15 A. M. King, M. De Ryck, R. Kaminski, A. Valade, J. P. Stables and H. Kohn, J. Med. Chem., 2011, 54, 6432-6442, DOI: 10.1021/jm200760a.

16 Y. Zhou, H. Wang, F. Guo, N. Si, A. Brantner, J. Yang, L. Han, X. Wei, H. Zhao and B. Bian, Molecules, 2018, 23, E2929, DOI: 10.3390/molecules23112929.
17 X. X. Liang, C. Xiong, M. He, C. He and Z. Yin, Lett. Drug Des. Discovery, 2016, 13, DOI: 10.2174/ 1570180813888160201100814.

18 B. Neises and W. Steglich, Angew. Chem., Int. Ed. Engl., 1978, 17(7), 522-524, DOI: 10.1002/anie.197805221.

19 V. Gilles, M. A. Vieira, V. Lacerda, E. V. R. Castro, R. B. Santos, E. Orestes, J. W. M. Carneiro and S. J. Greco, J. Braz. Chem. Soc., 2015, 26(1), 74-83, DOI: 10.5935/0103-5053.20140216.

20 P. Sahariah, B. E. Benediktssdóttir, M. Á. Hjálmarsdóttir, O. E. Sigurjonsson, K. K. Sørensen, M. B. Thygesen, K. J. Jensen and M. Másson, Biomacromolecules, 2015, 16(5), 1449-1460, DOI: 10.1021/acs.biomac.5b00163.

21 M. J. Waring, A. Arrowsmith, A. R. Leach, P. D. Leeson, S. Mandrell, R. M. Owen, G. Pairaudeau, W. D. Pennie, S. D. Pickett, J. Wang, O. Wallace and A. Weir, Nat. Rev. Drug Discovery, 2015, 14, 475-486, DOI: 10.1038/nrd4609.

22 J. A. Arnott and S. L. Planey, Expert Opin. Drug Discovery, 2012, 10, 863-875, DOI: 10.1517/17460441.2012.714363.

23 M. Alasmari, M. Böhlke, C. Kelley, T. Maher and A. PinoFigueroa, Mol. Neurobiol., 2019, 56, 1770-1781, DOI: 10.1007/s12035-018-1115-8.

24 D. Rengstl, O. Diat, R. Klein and W. Kunz, Langmuir, 2013, 29(8), 2506-2519, DOI: 10.1021/la304431c.

25 L. T. Apaza, M. C. Rodríguez, G. Potente and A. S. Rumbero, Planta Med. Int. Open, 2020, 7, e88-e99, DOI: 10.1055/a-11594242.

26 B. W. Gung, F. Wekesa and C. L. Barnes, J. Org. Chem., 2008, 73(5), 1803-1808, DOI: 10.1021/jo702354x.

27 T. Sander, J. Freyss, M. von Korff and C. Rufener, J. Chem. Inf. Model., 2015, 55, 460-473, DOI: 10.1021/ci500588j.

28 O. A. Stasyuk, H. Szatylowicz, T. M. Krygowski and C. Fonseca Guerra, Phys. Chem. Chem. Phys., 2016, 18(17), 11624-11633, DOI: 10.1039/c5cp07483e.

29 J. E. V. Ferreira, C. H. S. da Costa, R. M. de Miranda, A. F. Figueiredo and Y. M. A. Ginarte, Educ. Quim., 2014, 25(4), 418-424, DOI: 10.1016/s0187-893x(14)70061-8.

30 J. L. Moncada and G. S. Morán, Quim. Nova, 2008, 31(5), 1255-1258, DOI: 10.1590/s0100-40422008000500057.

31 S. Habtemariam, Planta Med., 2002, 66, 303-313, DOI: 10.1055/s-2000-8660. 